\title{
A GLOBAL SEA SURFACE CARBON OBSERVING SYSTEM: INORGANIC AND ORGANIC CARBON DYNAMICS IN COASTAL OCEANS
}

A.V. Borges ${ }^{(1)}$, S.R. Alin ${ }^{(2)}$, F.P. Chavez ${ }^{(3)}$, P. Vlahos $^{(4)}$, K.S. Johnson ${ }^{(3)}$, J.T. Holt ${ }^{(5)}$, W.M. Balch ${ }^{(6)}$, N. Bates ${ }^{(7)}$, R. Brainard ${ }^{(8)}$, W.-J. Cai ${ }^{(9)}$, C.T.A. Chen ${ }^{(10)}$, K. Currie $^{(11)}$, M. Dai ${ }^{(12)}$, M. Degrandpre ${ }^{(13)}$, B. Delille ${ }^{(14)}$, A. Dickson ${ }^{(15)}$, W. Evans ${ }^{(16)}$, R.A. Feely ${ }^{(2)}$, G.E. Friederich ${ }^{(5)}$, G.-C. Gong ${ }^{(17)}$, B. Hales ${ }^{(17)}$,

N. Hardman-Mountford ${ }^{(18)}$, J. Hendee ${ }^{(19)}$, J.M. Hernandez-Ayon ${ }^{(20)}$, M. Hood ${ }^{(21)}$, E. Huertas ${ }^{(22)}$, D. Hydes ${ }^{(23)}$,

D. Ianson ${ }^{(24)}$, E. Krasakopoulou ${ }^{(25)}$, Litt E. ${ }^{(26)}$, A. Luchetta ${ }^{(27)}$, J. Mathis ${ }^{(28)}$, W.R. McGillis ${ }^{(29)}$, A. Murata ${ }^{(30)}$, J. Newton ${ }^{(31)}$, J. Ólafsson ${ }^{(32)}$, A. Omar ${ }^{(33)}$, F.F. Perez ${ }^{(34)}$, C. Sabine ${ }^{(2)}$, J.E. Salisbury ${ }^{(35)}$, R. Salm ${ }^{(36)}$, V.V.S.S. Sarma ${ }^{(37)}$, B. Schneider ${ }^{(38)}$, M. Sigler ${ }^{(39)}$, H. Thomas ${ }^{(40)}$, D. Turk ${ }^{(41)}$, D. Vandemark ${ }^{(40)}$, R. Wanninkhof ${ }^{(23)}$, B. Ward ${ }^{(42)}$

${ }^{(1)}$ ULg (University of Liège), Allée du 6 Août, 17 (Bât B5) B-4000 Liège - Belgium, Email: alberto.borges@ulg.ac.be

(2) NOAA PMEL (National Oceanic and Atmospheric Administration/Pacific Marine Environment Laboratory), 7600 Sand Point Way N.E. Seattle, WA 98115-6349, USA, Email: simone.r.alin@noaa.gov; richard.a.feely@noaa.gov; chris.sabine@noaa.gov

(3) MBARI (Monterey Bay Aquarium Research Institute), 7700 Sandholdt Road, Moss Landing, CA 95039, USA, Email: chfr@mbari.org;johnson@mbari.org;frge@mbari.org

(4) UConn (University of Connecticut), 115 N Eagleville Rd, Storrs, CT 06268, USA, Email: penny.vlahos@uconn.edu

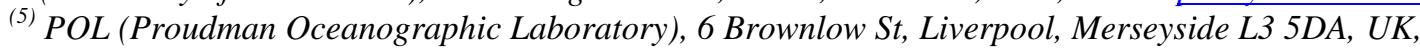
Email: jholt@pol.ac.uk

${ }^{(6)}$ BIGELOW (Bigelow Laboratory for Ocean Sciences), 180 McKown Point Road, P.O. Box 475, West Boothbay Harbor, Maine 04575-0475, USA, Email: bbalch@bigelow.org

(7) BIOS (Bermuda Institute of Ocean Sciences), 17 Biological Station, Ferry Reach, St. George's GE 01, Bermuda, Email: nick.bates@bios.edu

${ }^{(8)}$ NOAA PIFSC (National Oceanic and Atmospheric Administration/Pacific Islands Fisheries Science Center), 1125-B Ala Moana Blvd., Honolulu, HI 96814, USA, Email: rusty.brainard@noaa.gov

${ }^{(9)}$ UGA (University of Georgia), Athens, GA 30602USA, Email: wcai@uga.edu ${ }^{(10)}$ NSYSU (National Sun Yat-Sen University), 7, Lienhai Rd., Kaohsiung 80424, Taiwan, Email: ctchen@mail.nsysu.edu.tw

(11) NIWA (National Institute of Water \& Atmospheric Research), 41 Market Place, Viaduct Harbour, Auckland Central 1010, Private Bag 99940, Newmarket, Auckland 1149. New Zealand, Email: k.currie@niwa.co.nz

${ }^{(12)}$ XMU (Xiamen University), 361005 Fujian Province, P. R. China, Email: $\frac{\text { mdai@ @mu.edu.cn }}{\text { MT }}$

${ }^{(13)}$ UMONTANA (University of Montana), 32 Campus Drive \#1296 - Missoula, MT 59812-1296, USA, Email: michael.degrandpre@umontana.edu

${ }^{(14)}$ ULg (University of Liege), Allée du 6 Août, 17 (Bât B5) B-4000 Liège - Belgium, Email: bruno.delille@ulg.ac.be

${ }^{(15)}$ UCSD (University of California, San Diego), 9500 Gilman Drive, San Diego, La Jolla, CA 92093-0225, USA, Email: adickson@ucsd.edu

${ }^{(16)}$ OSU (Ohio State University), Enarson Hall 154 W 12th Avenue, Columbus, Ohio 43210,, USA, Email:wevans@coas.oregonstate.edu; bhales@coas.oregonstate.edu

(17) NTOU (National Taiwan Ocean University), 2 Pei-Ning Road, Keelung, Taiwan 20224, R.O.C., Email: gcgong@mail.ntou.edu.tw

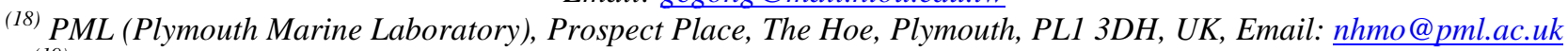
${ }^{(19)}$ NOAA AOML (National Oceanic and Atmospheric Administration/Atlantic Oceanographic and Meteorological

Laboratory), 4301 Rickenbacker Causeway, Miami, FL 33149, USA, Email: jim.hendee@noaa.gov; rik.wanninkhof@noaa.gov

${ }^{(20)}$ UABC (Universidad Autónoma de Baja California), Ensenada, Baja California, Apartado postal 2732, México, Email:jmartin@uabc.mx

${ }^{(25)}$ UNESCO-IOCCP (United Nations Educational, Scientific and Cultural Organization/International Ocean Carbon Coordination Project), 1 rue Miollis, 75732 Paris Cedex 15, France; Email: m.hood@ unesco.org

${ }^{(22)}$ ICMAN (Instituto De Ciencias Marinas De Andulacia), Campus Universitario Rio San Pedro, s/n. Puerto Real. Cadiz.E-11519, Spain,Email: emma.huertas@icman.csic.es

${ }^{(23)}$ SOTON (University of Southampton), Waterfront Campus, European Way SO14 5FD Southampton UK, Email: djh@noc.soton.ac.uk

${ }^{(24)}$ IOS (Institute of Ocean Sciences), 9860 West Saanich Road, PO Box 6000, Sidney V8L 4B2, B.C., Canada, Email: iansond@pac.dfo-mpo.gc.ca 
${ }^{(25)}$ HCMR (Hellenic Centre for Marine Research), PO Box 2214, 71003 Heraklion, Crete, Greece, Email: ekras@ath.hcmr.gr

(26) PML (Plymouth Marine Laboratory), Prospect Place, The Hoe, Plymouth, PL1 3DH, UK, Email: osp41a@bangor.ac.uk

(27) ISMAR (Istituto di Scienze Marine/Institute of Marine Sciences), Viale Romolo Gessi 2 - 34123 Trieste, Italia, Email: a.luchetta@ts.ismar.cnr.it

${ }^{(28)}$ UAF (University of Alaska Fairbanks), 907 Yukon Dr, Fairbanks, AK 99709, USA, Email: jmathis@sfos.uaf.edu

${ }^{(29)}$ LDEO (Lamont-Doherty Earth Observatory), 61 Route 9W, PO Box 1000; Palisades, New York 10964, USA, Email: wrm2102@ columbia.edu

(30) JAMSTEC (Japan Agency for Marine-Earth Science and Technology), 2-15 Natsushima, Yokosuka, Kanagawa, 237-0061 Japan, Email: murataa@jamstec.go.jp

${ }^{(31)}$ UW (University of Washington), 1013 N.E. 40th St., Seattle, WA 98105 USA, Email: newton@ocean.washington.edu

${ }^{(32)}$ HAFRO (Hafrannsóknastofnunin/Marine Research Institute), Skulagata 4, 121 Reykjavik, Iceland, Email: jon@hafro.is

${ }^{(33)}$ UIB (University of Bergen), Allegaten 70, 5007 Bergen, Norway, Email: abdirahman.omar@bjerknes.uib.no

${ }^{(34)}$ IIM (Instituto de Investigaciones Marina, C/Eduardo Cabello, 6. Vigo. Pontevedra. E-3620, Spain, Email:fiz.perez@iim.csic.es

${ }^{(35)}$ UNH (University of New Hampshire), 39 College Rd., Durham, NH 03824, USA, Email: joe.salisbury@unh.edu; doug.vandemark@unh.edu

${ }^{(36)}$ TNC (The Nature Conservancy), 4245 North Fairfax Drive, Suite 100, Arlington, VA 22203-1606 USA,

Email: rsalm@tnc.org

${ }^{(37)}$ NIO (National Institute of Oceanography), Dona Paula - 403 004, Goa, India,

Email: sarmav@nio.org

(38) IO-WARNEMUENDE (Leibniz Institute for Baltic Sea Research Warnemünde), Seestrasse 15, D-18119 Rostock Germany,Email: bernd.schneider@io-warnemuende.de

${ }^{(39)}$ NOAA AFSC (National Oceanic and Atmospheric Administration/Alaska Fisherines Science Center),7600 Sand Point Way N.E., Building 4, Seattle, Washington 98115 USA, Email: mike.sigler@noaa.gov

${ }^{(40)}$ DAL (Dalhousie University), 1355 Oxford St., Halifax, Nova Scotia B3H 4J1, Canada, Email: helmuth.thomas@dal.ca

${ }^{(41)}$ NIB (Nacionalni inštitut za biologijo/National Institute of Biology), Večna pot 111, 1000 Ljubljana, Slovenia, Email:daniela.turk@mbss.org

${ }^{(42)}$ NUI (National University of Ireland), 49 Merrion Square, Dublin 2, Ireland, Email: bward@nuigalway.ie

\section{EXECUTIVE SUMMARY}

Coastal environments are an important component of the global carbon cycle, and probably more vulnerable than the open ocean to anthropogenic forcings. Due to strong spatial heterogeneity and temporal variability, carbon flows in coastal environments are poorly constrained. Hence, an integrated, international, and interdisciplinary program of ship-based hydrography, Voluntary Observing Ship (VOS) lines, time-series moorings, floats, gliders, and autonomous surface vessels with sensors for $\mathrm{pCO}_{2}$ and ancillary variables are recommended to better understand present day carbon cycle dynamics, quantify air-sea $\mathrm{CO}_{2}$ fluxes, and determine future long-term trends of $\mathrm{CO}_{2}$ in response to global change forcings (changes in river inputs, in the hydrological cycle, in circulation, sea-ice retreat, expanding oxygen minimum zones, ocean acidification, ...) in the coastal oceans. Integration at the international level is also required for data archiving, management, and synthesis that will require multi-scale approaches including the development of biogeochemical models and use of remotely sensed parameters. The total cost of these observational efforts is estimated at about 50 million US dollars per year.

\section{INTRODUCTION}

\subsection{Carbon fluxes in the coastal oceans}

Continental shelf sea environments are an important component of the global carbon (C) cycle (Fig. 1), and more vulnerable than the open ocean to anthropogenic forcings. Continental shelf seas constitute one of the most biogeochemically active areas of the biosphere. They receive massive inputs of organic matter and nutrients from land and exchange large amounts of matter and energy with the open ocean across continental slopes. Globally, these transition zones support between $\sim 15 \%$ and $\sim 30 \%$ of oceanic primary 


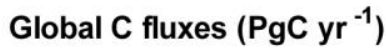

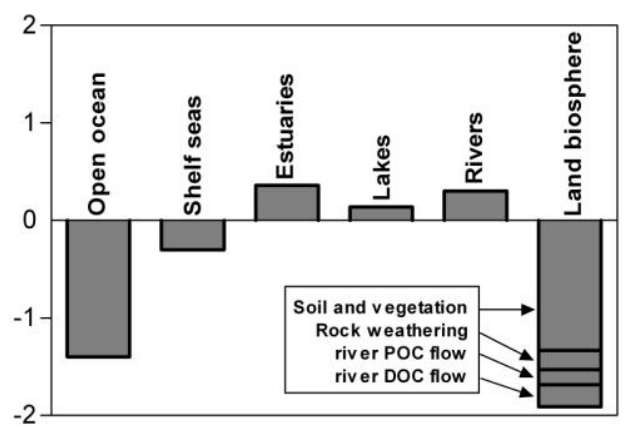

Relative surface area (\%)

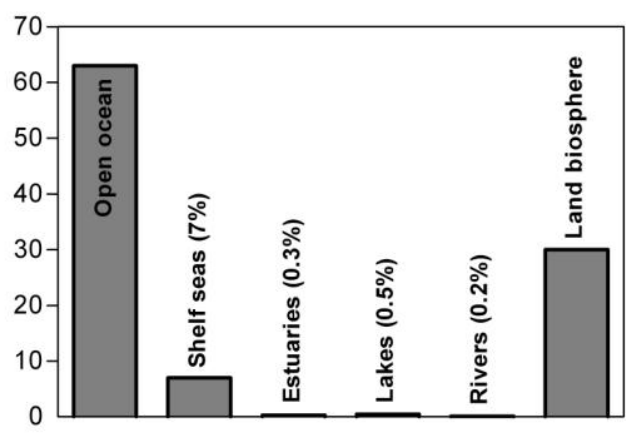

Figure 1 Global $\mathrm{CO}_{2}$ exchanges with the atmosphere $\left(\mathrm{PgC} y r^{-1}\right)$ in the open ocean (Takahashi et al. 2009), continental shelf seas and estuaries (Chen and Borges 2009), rivers (Cole and Caraco 2001), lakes (Cole et al. 1994), and land biosphere (vegetation and soils (Cole et al. 2007), rock weathering (Ludwig et al. 1996a), the export of DOC (Dissolved Organic Carbon) and POC (Particulate Organic Carbon) by rivers from land to ocean (Ludwig et al. 1996b)), and the relative surface area of continental shelf seas

(Walsh 1988), estuaries (Woodwell et al. 1973) and rivers and lakes (Lehner and Doll 2004). Note that the export of DOC and POC by rivers from land to ocean is a sink of atmospheric $\mathrm{CO}_{2}$ for the land

biosphere and source of $\mathrm{CO}_{2}$ from the coastal and open oceans (assuming remineralization to maintain steady state). Note that rock weathering is a sink of atmospheric $\mathrm{CO}_{2}$ for the land biosphere and source of $\mathrm{CO}_{2}$ from the coastal and open oceans (assuming marine calcification to maintain steady state).

production and $\sim 80 \%$ of oceanic organic matter burial (e.g. Gattuso et al. 1998a). In addition, they host most of the benthic marine $\mathrm{CaCO}_{3}$ production, $20 \%$ of surface pelagic oceanic $\mathrm{CaCO}_{3}$ stock (Balch et al. 2005), and $\sim 50 \%$ of oceanic $\mathrm{CaCO}_{3}$ deposition (Gattuso et al. 1998a). Hence, flows of carbon and nutrients are disproportionately high in comparison with the surface area ( $<7 \%$ of total oceanic surface area). Based on literature compilations, the contemporary sink of $\mathrm{CO}_{2}$ has been estimated to range between 0.2 and $0.4 \mathrm{PgC} \mathrm{yr}^{-}$ ${ }^{1}$ (Borges 2005, Borges et al. 2005, Cai et al. 2006, and Chen \& Borges 2009).

This sink corresponds to $14 \%$ to $29 \%$ of the most recent estimate of the contemporary open ocean sink for atmospheric $\mathrm{CO}_{2}$ of $1.4 \mathrm{PgC} \mathrm{yr}{ }^{-1}$ (Takahashi et al. 2009). However, to date, available estimates of present day air-sea $\mathrm{CO}_{2}$ fluxes in the coastal oceans suffer from several caveats (see Sect. 2.1). The net air-sea exchange of $\mathrm{CO}_{2}$ is the small difference among several much larger input and output gross fluxes of carbon to the coastal oceans (river inputs, export to the open ocean, exchange with the sediments, etc.) (Vlahos et al 2002). Global change forcings that result in changes to any of these larger coastal carbon fluxes may thus result in proportionally larger changes to the global net air-sea $\mathrm{CO}_{2}$ exchange in coastal oceans. It is critical to better constrain the magnitude and controls on the major coastal ocean carbon fluxes to improve our ability to predict future changes to $\mathrm{CO}_{2}$ fluxes in coastal oceans based on a process-level understanding.

Carbon dioxide $\left(\mathrm{CO}_{2}\right)$ is the form of dissolved inorganic carbon (DIC $\left.=\left[\mathrm{CO}_{2}\right]+\left[\mathrm{HCO}_{3}{ }^{-}\right]+\left[\mathrm{CO}_{3}{ }^{2-}\right]\right)$ used in photosynthesis by autotrophs, remineralized by heterotrophs and exchanged across the air-sea interface. It is essential to improve our understanding of the dynamics of the DIC system, and the quantification of air-sea $\mathrm{CO}_{2}$ fluxes over daily, to seasonal, to interannual and decadal time-scales. Synoptic estimates based on field data using a variety of platforms, based on remotely sensed data and on modelling of the full spatial extent of the coastal ocean are necessary to understand the diversity of biogeochemical $\mathrm{C}$ cycling related to extremely varied physical and biogeochemical settings. The dynamic, rapidly evolving nature of these environments presents a major challenge for the development of appropriate observing systems.

Carbon cycle dynamics in coastal environments can shift rapidly, particularly in response to changes in nutrient and organic matter inputs that may lead to longterm changes in $\mathrm{CO}_{2}$ sequestration (e.g. Mackenzie et al. 2004) or to rapid decadal shifts in source or sink status for atmospheric $\mathrm{CO}_{2}$ (Gypens et al. 2009). So far, due to lack of adequate data-sets, long-term changes in $\mathrm{CO}_{2}$ dynamics in coastal environments have only been investigated through a few relatively simple numerical models (Mackenzie et al. 2004; Gypens et al. 2009), and a few data-based studies (Bering and Okhotsk Seas: Murata (2006); Takahashi et al. (2006); Barents Sea: Omar et al. (2003); North Sea: Thomas et al. (2007); California Current: Fig. 2). 


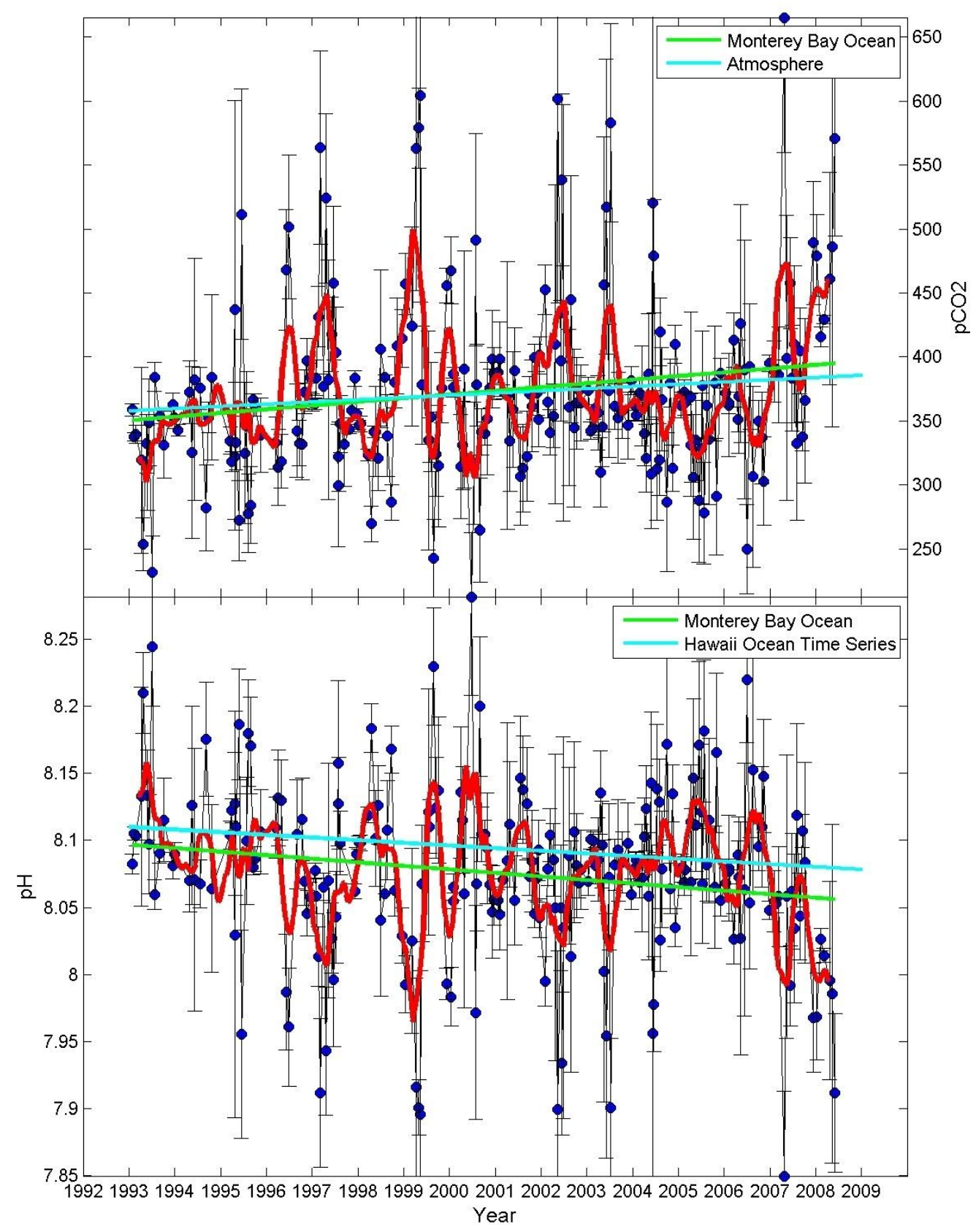

Figure 2 Time-series of sea surface p $\mathrm{C}_{2}$ and pH from Monterey Bay, California (F.P. Chavez, unpublished). The blue dots are averages of a $50 \mathrm{~km}$ underway transit. The red line is interpolated and smoothed. The green line is the trend. In light blue are the regression lines for atmospheric $\mathrm{pCO}_{2}$ from Mauna Loa and sea surface $\mathrm{pH}$ from the Hawaii Ocean Time series (HOT) published in Doney et al. (2009). The slow and steady uptake of atmospheric $\mathrm{CO}_{2}$ by the oceans has been observed in the open-ocean time series off Hawaii but now it can clearly be detected in Monterey Bay - a surprise given the strong variability on daily to interannual time scales in ocean $\mathrm{pCO}_{2}$ due to coastal upwelling and the resulting biological production. Multi-decadal variations are driving an increase of subsurface $\mathrm{pCO}_{2}$, thereby accelerating the rate of increase of $\mathrm{CCO}_{2}$ relative to the atmosphere. As a result $\mathrm{pH}$ is decreasing faster than in the open ocean. 
Very similar dynamic ranges and spatiotemporal variability have been observed in the carbon cycles of island coastal environments not associated with continental shelf settings (Bates 2002; Fagan and Mackenzie 2007; Paquay et al. 2007). While these island coast environments have not typically been included in large-scale or global carbon cycle syntheses, many are also substantially more prone to anthropogenic impacts than remote open ocean ecosystems by virtue of proximity to population centers and relatively restricted circulation. We include the requirements of island coastal settings with respect to global carbon cycle observations in this community white paper to acknowledge that many of the same global change factors apply to carbon cycles processes in both island and continental shelf environments, although we anticipate that a distinction will be made between island and continental margin observational resources in how they will be used for future synthesis and monitoring efforts.

\subsection{Vulnerability and possible future evolution}

The coastal oceans are more vulnerable to anthropogenic forcings than the open ocean. Potential feedbacks between marine organisms and communities and anthropogenic $\mathrm{CO}_{2}$ forcing are expected to be disproportionately important in the coastal ocean compared to the open ocean, due to the larger fluxes of organic and inorganic carbon. These diverse anthropogenic forcings are considered as follows:

- Changes in circulation and stratification. It has been hypothesized (Bakun 1990) and modelled (Snyder et al. 2003; Diffenbaugh et al. 2004) that the intensity and duration of coastal upwelling will increase in the future due to climate change. This has to some extent been confirmed by observations in some (McGregor et al. 2007) but not all (Di Lorenzo et al. 2005; Field et al. 2006) coastal upwelling systems. The response of air-sea $\mathrm{CO}_{2}$ fluxes to increased upwelling is difficult to predict and can go both ways. Stronger vertical inputs of DIC would drive the system to emit more $\mathrm{CO}_{2}$ to the atmosphere, while enhanced nutrient inputs would drive higher primary production, export production and a sink for atmospheric $\mathrm{CO}_{2}$. Long-term observations such as in the California Current (Fig. 2) are needed to unravel the response of coastal upwelling systems to global changes.

- Climate change is expected to lead to a future decrease of oxygen $\left(\mathrm{O}_{2}\right)$ content in the oceans due to thermohaline circulation slowing down and the decreasing solubility of $\mathrm{O}_{2}$ with surface warming of the source waters from intermediate and deep layers (e.g., Bopp et al. 2002; Matear and Hirst 2003). This will lead to the expansion of oxygen minimum zones (OMZ) as confirmed by historical observations (Bograd et al. 2008; Stramma et al. 2008). OMZ are associated with major coastal upwelling regions that act as sources of $\mathrm{CO}_{2}$ to the atmosphere because denitrification leads to low concentrations of nitrate and an excess of DIC relative to nitrogen (Friederich et al. 2008; Paulmier et al. 2008). Coastal upwelling areas without OMZ such as the Iberian coastal upwelling system (Borges and Frankignoulle 2002a) or with deep OMZ such as the Oregon coast (Hales et al. 2005) are currently sinks for atmospheric $\mathrm{CO}_{2}$. However, the future horizontal and vertical expansion of $\mathrm{OMZ}$ is expected to provide positive feedback on increasing atmospheric $\mathrm{CO}_{2}$ due to enhanced $\mathrm{CO}_{2}$ emissions from coastal upwelling systems.

- Retreat of sea-ice in the Arctic Ocean. Coastal waters in the Arctic Ocean are known to act as a strong sink for atmospheric $\mathrm{CO}_{2}$ due to low temperature (Murata and Takizawa 2002) and high primary production (Bates 2006). The physical and biogeochemical conditions driving the $\mathrm{CO}_{2}$ sink are affected by spatial and temporal variations of sea-ice distributions. Thus, future sea-ice loss will impact air-sea exchange of $\mathrm{CO}_{2}$.

- Land-use activities (agriculture, deforestation, urbanization) are changing the fluxes to the coastal ocean of suspended sediments (Milliman 1991; Vörösmarty et al. 2003), organic carbon (Meybeck 1993), total alkalinity (Raymond and Cole 2003; Cai et al. 2008) and nutrients (Smith et al. 2003). These fluxes to the coastal ocean will be further modified by changes in river discharge that are forced by climate change impacts on the hydrological cycle (e.g. Manabe et al. 2004, Peterson et al. 2006), and dam-building and river diversion activities (Vörösmarty and Sahagian 2000). Existing numerical models (Mackenzie et al. 2004; Gypens et al. 2009) suggest these changes in inputs have already changed and will continue to change air-sea $\mathrm{CO}_{2}$ fluxes on decadal and longer time scales.

- Key species and communities in many coastal ecosystems are threatened by direct and indirect human impacts, with implications for net carbon fluxes in these environments. For instance, losses in seagrass (Short and Neckles 1999; Duarte 2002) and coral reef ecosystems (Hughes et al. 2003) have been observed and are predicted to continue due to mechanical damage (dredging and anchoring), as well as eutrophication and siltation, with the latter two leading to light limitation. Negative indirect human impacts on seagrass and coral ecosystems include increases of erosion by sea level rise, frequency and intensity of extreme weather events, ultraviolet irradiance, and water temperature. Other 
coastal ecosystems, such as mangrove forests or saltmarshes, are relatively resilient to present and future hydrological changes, pollution, and global warming, but in some parts of the world they are being cleared for urban development and aquaculture (Alongi 2002).

- The increase of surface water DIC due to the invasion of anthropogenic $\mathrm{CO}_{2}$ will generally decrease the $\mathrm{CaCO}_{3}$ saturation state with potential decline of $\mathrm{CaCO}_{3}$ production in benthic (Gattuso et al. 1998b; Kleypas et al. 1999) and planktonic (Riebesell et al. 2000; Zondervan et al. 2002; Delille et al. 2005) communities and enhancement of shallow-water $\mathrm{CaCO}_{3}$ dissolution (Andersson and Mackenzie 2004). The increase of seawater $\mathrm{CO}_{2}$ concentration due to the invasion of anthropogenic $\mathrm{CO}_{2}$ could also enhance primary production for at least some phytoplanktonic species, as reviewed by Wolf-Gladrow et al. (1999). Anthropogenic $\mathrm{CO}_{2}$ uptake may also affect pelagic carbon export by stimulating the production of transparent exopolymer particles (e.g., Engel et al. 2004) or altering the elemental stoichiometry of uptake, accumulation, and loss processes (e.g., Riebesell et al. 2007).

- In coastal environments, the acidification of surface waters could be enhanced compared to the open ocean due to anthropogenic atmospheric nitrogen and sulfur deposition (Doney et al. 2007), upwelling of anthropogenically "acidified" DIC-rich waters (Feely et al. 2008), or river inputs (Salisbury et al. 2008; Chierici and Fransson, 2009). On the other hand, the effect of acidification on surface water carbonate chemistry could be modulated by enhanced primary production related to eutrophication (Gypens et al. 2009) or by the increase of the buffering capacity of seawater related to enhanced total alkalinity fluxes from rivers (Raymond and Cole 2003; Cai et al. 2008; Raymond et al. 2008).

- In some coastal environments, the high levels of organic matter present in sediments support anaerobic degradation processes, which increase the total alkalinity of the overlying water and increase the potential for carbon storage (Chen 2002; Thomas et al. 2009). This may also be true for salt-marsh surrounded estuaries and shelves where total alkalinity production is significant (Cai and Wang 1998; Cai et al. 2003). This increase of total alkalinity is mainly related to dentrification, and the impact of reduced primary production due to the removal of nitrate does not compensate for the increase of total alkalinity in terms of air-sea $\mathrm{CO}_{2}$ fluxes (Fennel et al. 2008).

\section{SCIENTIFIC OBJECTIVES AND RATIONALE}

The principal scientific objectives for a sustained coastal carbon observational network are:

1. to improve estimates of spatial and temporal variability of carbon fluxes in coastal oceans;

2. to understand the processes controlling coastal carbon balance and how these processes are affected by natural and anthropogenic drivers; and

3. to develop the detection and prediction capacity to forecast long-term changes of $\mathrm{CO}_{2}$ dynamics in coastal oceans in response to global changes (changes in river inputs, in the hydrological cycle, in circulation, sea-ice retreat, expanding oxygen minimum zones, ocean acidification, ...).

To achieve these objectives the community needs to:

1. improve existing technology and develop new methodology for measurements of $\mathrm{CO}_{2}$ and ancillary variables;

2. develop an observational network using a multitude of platforms : VOS lines, moorings, drifters, gliders, autonomous surface vessels, and process-oriented research cruises;

3. bank and manage quality checked data; and

4. synthesize data using several approaches such as biogeochemical models and use of remotely sensed products.

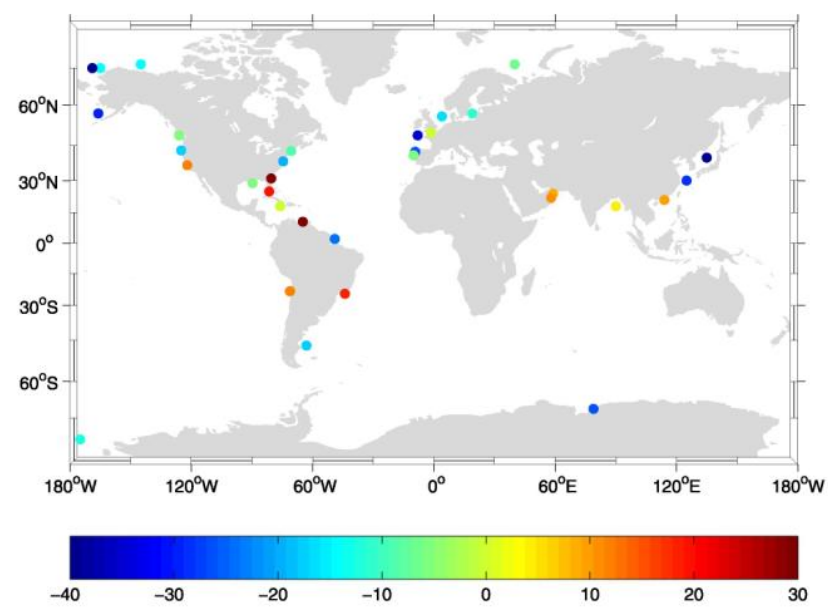

Figure 3 Distribution of sites used in the compilation of

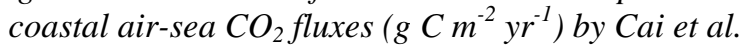
(2006). Data coverage and distribution is similar to the other literature compilations by Borges (2005), Borges et al. (2005) and Chen \& Borges (2009). 


\subsection{Observational needs for improving estimates of net global air-sea exchange in coastal oceans}

To date, available estimates of present-day air-sea $\mathrm{CO}_{2}$ fluxes in the coastal oceans suffer from several limitations:

- Literature data compilations are based on $\mathrm{pCO}_{2}$ data sets that are not necessarily quality checked and at the standards of present day standard operating procedures (SOP). Published air-sea $\mathrm{CO}_{2}$ flux estimates have been computed using different parameterizations of gas transfer velocity as a function of wind speed and different sources of wind speed data.

- Published studies also lack sufficient data coverage to adequately characterize the spatial and ecosystem variability of coastal environments (Fig. 3). In particular, coastlines of the Russian Arctic, western South America, eastern Africa, large sections of western Africa, and most of Antarctica are dramatically under-sampled.

- Due to the large temporal and spatial variations of the partial pressure of $\mathrm{CO}_{2}\left(\mathrm{pCO}_{2}\right)$ in coastal environments (Fig. 4), air-sea $\mathrm{CO}_{2}$ fluxes can be biased by inadequate spatial or temporal coverage. The relative inadequacy of spatial and temporal coverage exists even for many shelves that have already been surveyed, i.e. in the East China Sea (Zhai and Dai, 2009), in the Southern Bight of the North Sea (Thomas et al. 2004; Schiettecatte et al. 2007), or the U.S. South Atlantic Bight (Cai et al. 2003; Jiang et al. 2008).

- Temporal scales range from diurnal (Dai et al., 2009) to inter-annual variations of air-sea $\mathrm{CO}_{2}$ fluxes due to global climate oscillations (El NiñoSouthern Oscillation: Friederich et al. 2002; Southern Annular Mode: Borges et al. 2008a). In near-shore ecosystems, variable river influence (Borges et al. 2008b; Gledhill et al. 2008; Salisbury et al. 2009) can also be particularly important in driving inter-annual variability of air-sea $\mathrm{CO}_{2}$ fluxes.

Overall, adequate data-sets generally do not exist to quantify the true scale of processes both regionally and globally. Recommendations to overcome these issues are addressed in Sect. 3.

\subsection{Extrapolating surface carbon observations through remote sensing and synthesis methods}

Remote sensing techniques have been successfully applied in the open ocean to extend surface $\mathrm{pCO}_{2}$ observations and evaluate air-sea $\mathrm{CO}_{2}$ fluxes (e.g., Lefèvre et al. 2002; 2004; Rangama et al. 2005; Friedrich and Oschlies 2009; Telszewski et al. 2009).
Algorithms are typically based on remotely sensed chlorophyll-a and sea surface temperature (SST), occasionally also based on modeled or climatological mixed layer depth or geographical position (latitude and longitude). These algorithms use multiple linear regression (Lefèvre et al. 2002; 2004; Rangama et al. 2005 ) or more recently neural network techniques (Lefèvre et al. 2005; Jamet et al. 2007; Friedrich \& Oschlies 2009; Telszewski et al. 2009). In coastal waters, remote sensing techniques have been used on a few studies to evaluate $\mathrm{pCO}_{2}$ (Salisbury et al. 2008), airsea $\mathrm{CO}_{2}$ fluxes (Olsen et al. 2004; Lohrenz and Cai 2006), and carbonate chemistry (Gledhill et al. 2008). Yet, in coastal waters, particularly in near-shore areas, the use of remote sensing techniques is more complex than in the open ocean:

- Coastal waters have more complex optical properties due to interference from suspended matter and colored dissolved organic matter (CDOM), and usually require specific atmospheric corrections due to the presence of neighboring land masses (e.g., Ruddick et al. 2000).
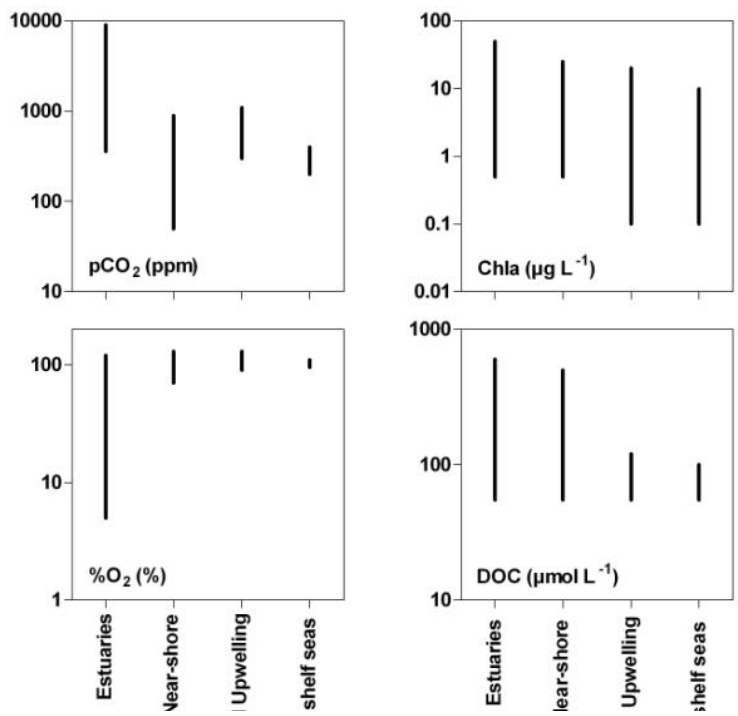

Figure 4 Range of spatio-temporal variability across different coastal environments of the partial pressure of $\mathrm{CO}_{2}\left(\mathrm{pCO}_{2}\right)$, oxygen saturation level $\left(\% \mathrm{O}_{2} \%\right)$, chlorophyll-a (Chla) and dissolved organic carbon (DOC) based on Borges \& Frankignoulle (2002a; $b$; c), Bouillon et al. (2003), Cai et al. (2003), Chavez \& Messié (2009), Cloern \& Jassby (2008),

Frankignoulle et al. (1998; 1996), Frankignoulle \& Borges (2001), Abril et al. (2002), Friedrich et al. (2002; 2008), García-Muñoza et al. (2005), Goyet et al. (1998), Kulinski and Pempkowiak (2008),

Okkonen et al. (2004), Raimbault et al. (2007), Shin \& Tanaka (2004) 
In river-influenced areas, sea surface salinity (SSS) data are usually required as an additional variable in the algorithms. SSS can be derived in some cases from climatological fields (Gledhill et al. 2008), from remotely sensed images relying on CDOM (Lohrenz and Cai 2006), or other optical properties (Salisbury et al. 2008) although this is not necessarily the case at all coastal sites (K. Ruddick, personal communication). The situation could be improved by the NASA Aquarius mission (e.g. Lagerloef et al. 2010), although the expected resolution of SSS data $(\sim 100 \mathrm{~km})$ will be too coarse for systems influenced by medium and small rivers. The most realistic and reliable options probably lie in the use of SSS fields from regional physical models, or from remotely sensed images relying on regional SSS-CDOM algorithms.

Self-organizing neural network approaches using remotely sensed chlorophyll-a, SST, and other variables can also be used to classify coastal areas into biogeochemical regions or provinces (e.g., Oliver et al. 2004; Chen and Zhang 2009) and improve the development and application of algorithms to scale data and derive $\mathrm{pCO}_{2}$ fields.

While regional studies can be carried out without international coordination, if such an approach is applied globally, coordination will be required to define areas to be covered and ensure that the approaches are methodologically similar enough to derive comparable results. Application of remotely sensing techniques must go hand-in-hand with the improvement of related products, in particular in the optically complex case-II waters.

\subsection{Observational needs for measuring other carbon fluxes and related parameters}

Measurements of air-sea $\mathrm{CO}_{2}$ fluxes provide only a small component of the carbon cycling and exchange that is occurring in coastal zones. It is necessary to provide a full carbon balance that incorporates both organic and inorganic pools measured with similar spatial and temporal resolution to constrain carbon budgets in these dynamic regions. Though the magnitude of the inorganic carbon pool is much greater than the organic carbon pool, gradients of both pools are the same order of magnitude (Vlahos et al. 2002) and readily comparable. Currently there are no in situ methods for the accurate detection of total and dissolved organic carbon pools. The development of such techniques needs to be a priority. Optical properties of DOM may provide useful proxies in areas with relatively consistent sources. These however fall apart in transition zones where there are shifts in the nature of the organic matter along the shelf. Thus, at this time, it is still very important to continue global scale measurements of coupled organic and inorganic carbon in coastal systems. Priorities include:

1. Regional differences based on hydrodynamics, frontal zone interactions and upwelling are very important in predicting shifts in the OC pool and carbon fluxes. A comprehensive study of continental shelves representative of latitudinal and hydrodynamic differences has begun (Liu et al. 2009) though much more is needed.

2. More information is needed on the diel changes that both organic and inorganic pools undergo in order to couple hydrodynamics to these varying concentrations.

3. Changing temperatures will lead to shifts in populations and net ecosystem production. Some of these changes may be predicted by comparing the known trophic status and carbon dynamics of continental shelf regions that may resemble the predicted conditions for another shelf region. Efforts to consolidate carbon data sets will augment this predictive ability.

4. Also, decreases in sea ice cover will increase the contribution of the organic carbon pool as primary productivity increases. Understanding the magnitude of these changes is imperative for carbon cycling and climate prediction.

Carbon flux through the air-sea interface is strongly modulated by net community production and particulate organic carbon (POC) export in the surface ocean (Chavez et al., 2007). Our understanding and skill in prediction of the air-sea $\mathrm{CO}_{2}$ flux in coastal regions will be greatly improved with observations of net community production (NCP) and POC export on spatial and temporal scales similar to those of air-sea flux. NCP and POC export are often not possible to measure with the same resolution that $\mathrm{pCO}_{2}$ can be observed using underway mapping systems and there are too few ship-based time-series stations to provide the required temporal or spatial resolution. Satellite ocean color observations are the only large-scale proxy that is available, and these observations are often difficult to interpret in coastal regions. However, it is now possible to use chemical sensors for carbon, oxygen or nitrate that are deployed on moorings (Johnson et al., 2006; Kortzinger et al., 2008; Martz et al., 2009) or profiling floats (Riser and Johnson, 2008; Martz et al., 2008) to estimate NCP with daily resolution. Autonomous observations with chemical sensors in the coastal environments can be used to assess NCP over multiple years (Johnson et al., 2006; Johnson 2009). This capability allows the impacts of changing biogeochemical processes on air-sea $\mathrm{CO}_{2}$ fluxes to be quantified rigorously. 


\subsection{Developing an ocean acidification observational network for coastal oceans}

A detailed description of an ocean acidification observational network for open and coastal oceans is given by Feely et al. (2009). In brief, the principal scientific objectives for a sustained ocean acidification observational network are: 1) determining the largescale ocean physical, chemical and biological water property changes; and 2) improving existing technology and developing new methodology for elucidating the variability of seawater chemistry and for evaluating the responses of organisms to the changes that take place. The main approaches are: 1) repeat surveys of chemical and biological properties; and 2) time-series measurements at fixed stations and on floats and gliders. The relevant variables are: $\mathrm{pCO}_{2}, \mathrm{pH}$, DIC or total alkalinity, oxygen, PIC (particulate inorganic carbon), POC (particulate organic carbon), bio-optical properties.

\subsection{Modeling needs for the coastal carbon cycle and ocean acidification impacts}

Coupled physical and biogeochemical models with the required resolution to adequately simulate DIC dynamics in coastal environments are limited and of local to regional scale, and should be expanded to global scale. Global climatologies and future scenarios of forcing variables for the models are needed or can be improved (rivers inputs of organic and inorganic carbon and nutrients ...). Inclusion of predictive power in such models is urgently needed, in the context of evaluation of the response to global changes and related impacts on $\mathrm{C}$ cycling $\left(\mathrm{CO}_{2}\right.$ fluxes and carbon export and sequestration), fisheries ... Major potential drivers of global changes on $\mathrm{C}$ cycling in the coastal oceans are:

- Changes in circulation and stratification (change of upwelling intensity, expansion of OMZ, sea-ice retreat ...)

- Changes in land-ocean fluxes of suspended sediments, DIC, DOC, POC and nutrients

- Changes in atmospheric deposition

- Ocean acidification

(Refer to Sect. 1.2 for details)

Coupled hydrodynamic ecosystem models represent a unique tool for investigating biogeochemical cycles through their ability to provide a complete, synoptic description of fluxes and budgets. They can also make mechanistic predictions. Their reliability is, however, substantially limited by the availability of observations of key components of the carbon cycle at appropriate spatial and temporal resolution. These are required for model calibration (parameter estimation) and validation both of the mean state and the important cycles (seasonal, inter-annual and eventually multi-decadal). It is only by demonstrating a model's ability to reproduce response to climate variability that we can gain confidence in its ability to predict the response to future climate change.

Since coastal/shelf seas form an important component of the Earth System, the goal is to include an adequate representation of these regions in fully coupled Earth System Models that link atmosphere, ocean and terrestrial systems. However, issues of resolution substantially restrict our efforts in this direction. For example, the wavelength and adjustment length (Rossby Radii) of long barotropic and baroclinic waves both tend to scale by h0.5 so decreases by an order of magnitude as the water depth reduces from $4000 \mathrm{~m}$ to $40 \mathrm{~m}$. Hence, the barotropic Rossby radius at mid-latitudes is $\sim 200$ $\mathrm{km}$ and the baroclinic Rossby radius is typically $2-20$ $\mathrm{km}$. The dynamic scales in turn determine the scales of the distribution of material transported from the landsea interface, such as in river plumes/coastal currents (1-300 km globally; Warrick and Fong, 2004), and exchange processes at fronts. From the scale of the ocean models used in the IPCC 4th assessment report, it is immediately apparent that the current generation of coupled climate models is a long way from being able to represent shelf-sea processes. These models have typical resolution of $1-2^{\circ}$ often with some enhancement at the equator. Only the MIRICO3.2 (hi-res) model at $0.2812^{\circ}$ longitude by $0.1875^{\circ}$ latitude can start to resolve the barotropic Rossby radius in mid-latitude coastal seas. Ocean general circulation models (OGCMs) coupled to ecosystem models tend to be at the coarse end of this range. Peta-scale computing provides the computational resources to address these issues, and variable resolution models (unstructured grid, e.g. Pain et al. 2005) provide the technology to do this highly efficiently. Recently multi-scale, unstructured grid models such as this are being run coupled to simple ecosystem models (Ji et al. 2008). While this example only considers a regional simulation, expansion to ocean basin and eventually global scales and incorporation into Earth Systems Models will come in due course.

While there is a general consensus for the development pathway of the hydrodynamic model, this is not the case for the representation of the ecosystem. Contentious areas include appropriate complexity, parameter assignment and relation to observations. These are reviewed by Allen et al.(2010). Issues that specifically relate to the carbon cycle are de-coupling nutrient and carbon cycles (Patsch and Kuhn 2008), ocean-shelf exchange (Holt et al. (2009)), and terrestrial inputs. On the latter, the need to know the total alkalinity (for partitioning the DIC) is a particular issue, since while the relationships with salinity are accurate, they are 
generally regionally specific and mostly developed for open ocean conditions to date (e.g. Lee et al. 2006).

\section{STRATEGY FOR A COASTAL CARBON OBSERVATIONAL NETWORK}

\subsection{Underway observations of carbon parameters on ships of opportunity}

There is a need for the deployment of additional autonomous $\mathrm{pCO}_{2}$ instrumentation on research and commercial Voluntary Observing Ships (VOS) to improve the spatial coverage of $\mathrm{pCO}_{2}$ and other carbon and ancillary parameters in surface waters. The map in Figure 5 shows known underway carbon observation lines on commercial and research ships for oceanic carbon observations. For $\mathrm{CO}_{2}$, the bulk of the effort has focused on the open ocean but some of these lines have covered parts of the coastal ocean. Recently underway observational systems have been installed on research and commercial vessels serving predominantly coastal regions. However, increased use of the VOS approach in continental shelf seas must be encouraged.

It is particularly recommended that in coming years research or commercial ships are instrumented to cover under-sampled regions such as the coastlines of the Russian Arctic, western South America, eastern Africa, large sections of western Africa, and most of Antarctica. It is also recommended that $\mathrm{pCO}_{2}$ and other carbon data obtained in coastal waters by "open ocean" dedicated VOS lines (e.g., Monteiro et al. 2010) should be processed and banked and not discarded.

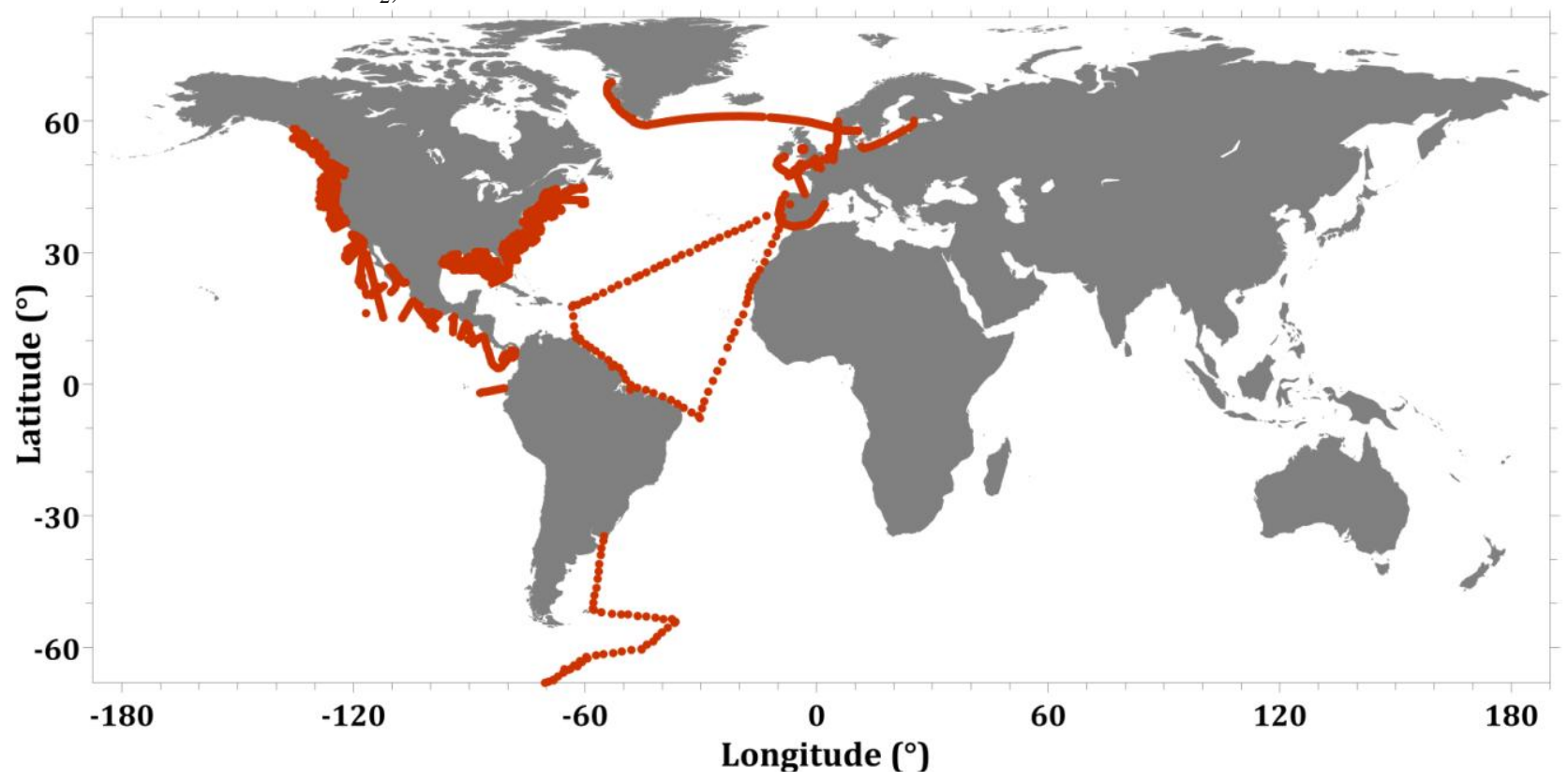

Figure 5 Carbon underway map: on-going and planned track lines (details in Tab 3)

3.2. Time-series measurements at fixed stations, on floats, gliders and autonomous surface vessels

Moorings can provide useful high-resolution observations at key sites where specific processes need to be studied with high temporal resolution and cannot be sampled by other means. As existing VOS lines have at best a weekly frequency, the VOS observatory needs to be complemented by moorings to provide information on temporal variability of $\mathrm{pCO}_{2}$ at higher frequency (daily or sub-daily scale) and capture shortterm extreme events (phytoplankton blooms, storms, high run-off, etc.) that are missed by VOS lines or even avoided (e.g. storms, hurricanes).

Moorings, floats, gliders and autonomous surface vessels should be equipped with a variety of automated sensors $\left(\mathrm{pCO}_{2}, \mathrm{pH}, \mathrm{SSS}, \mathrm{SST}, \mathrm{O}_{2}\right.$, chlorophyll-a, turbidity, inorganic nutrients, etc., as detailed in Sect. 2.4.) depending on the scientific issues addressed, such as $\mathrm{C}$ metabolism, ocean acidification (Feely et al. 2009), eutrophication, and so on. For instance, moorings in the open ocean equipped with $\mathrm{O}_{2}$ sensors have provided high temporal resolution estimates of C production and export (Karl et al. 2003; Emerson et al. 2008) and can be also be deployed in coastal environments (e.g., Fig. 6).

Moorings require that equipment is designed to be robust to biological fouling. Modern methods of power generation mean that the power consumption of instruments is less of a constraint than it has been.

Drifting instrument packages have been used successfully in the open oceans and could be adapted 

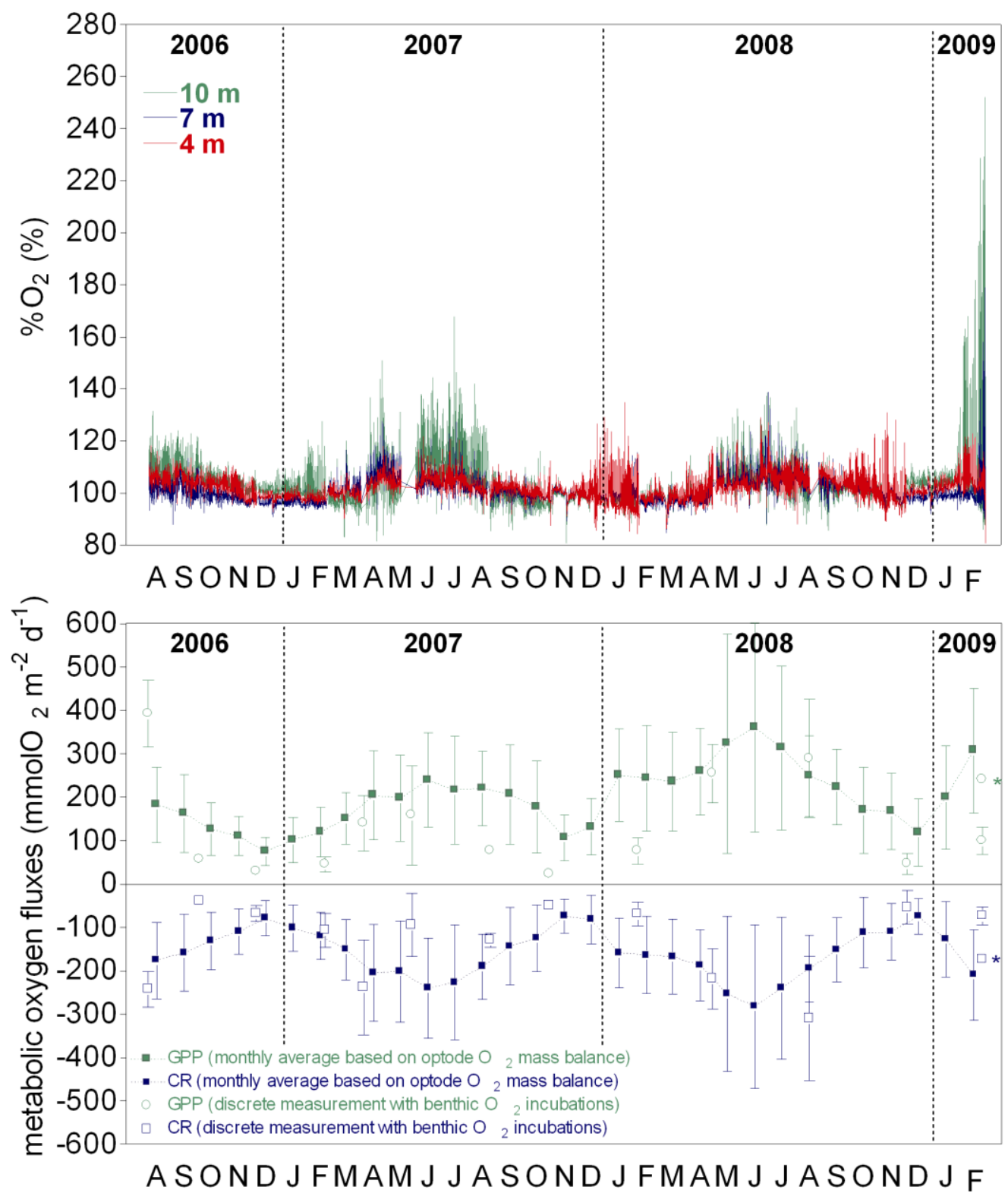

Figure 6 Time-series of oxygen saturation level on a shallow mooring (10m depth) over a Posidonia oceanica seagrass meadow in the Mediterranean Sea and gross primary production and community respiration derived from diel cycles of $\% \mathrm{O}_{2}$ measured on the mooring (monthly averages) and measured discretely with benthic chambers (A.V. Borges, unpublished).

for use in shelf seas. Currently gliders have the capacity to conduct cross-shelf depth profile transects of salinity, temperature, oxygen, chlorophyll-a, chromophoric dissolved organic matter, and turbidity. Sufficiently compact instruments to measure $\mathrm{pH}$ from a glider platform are under development, but there is a need for other inorganic carbon sensors to be developed for deployment on gliders.

The map in Fig. 7 shows known moorings and repeat stations for oceanic carbon observations. Such observations are lacking in most coastal waters with the exception of the U.S. east and west coasts, some sites in Europe, and some in India. It is recommended that in the coming years, mooring or repeat stations are developed to cover other areas of the coastal ocean.

While large-scale surveys can only be made with relatively low frequency, selected repeat stations similar to open ocean stations (HOT, BATS (Bermuda Atlantic Time-series Station), ESTOC (European Station for Time Series in the Ocean, etc...) should be developed in coastal environments to provide important information 


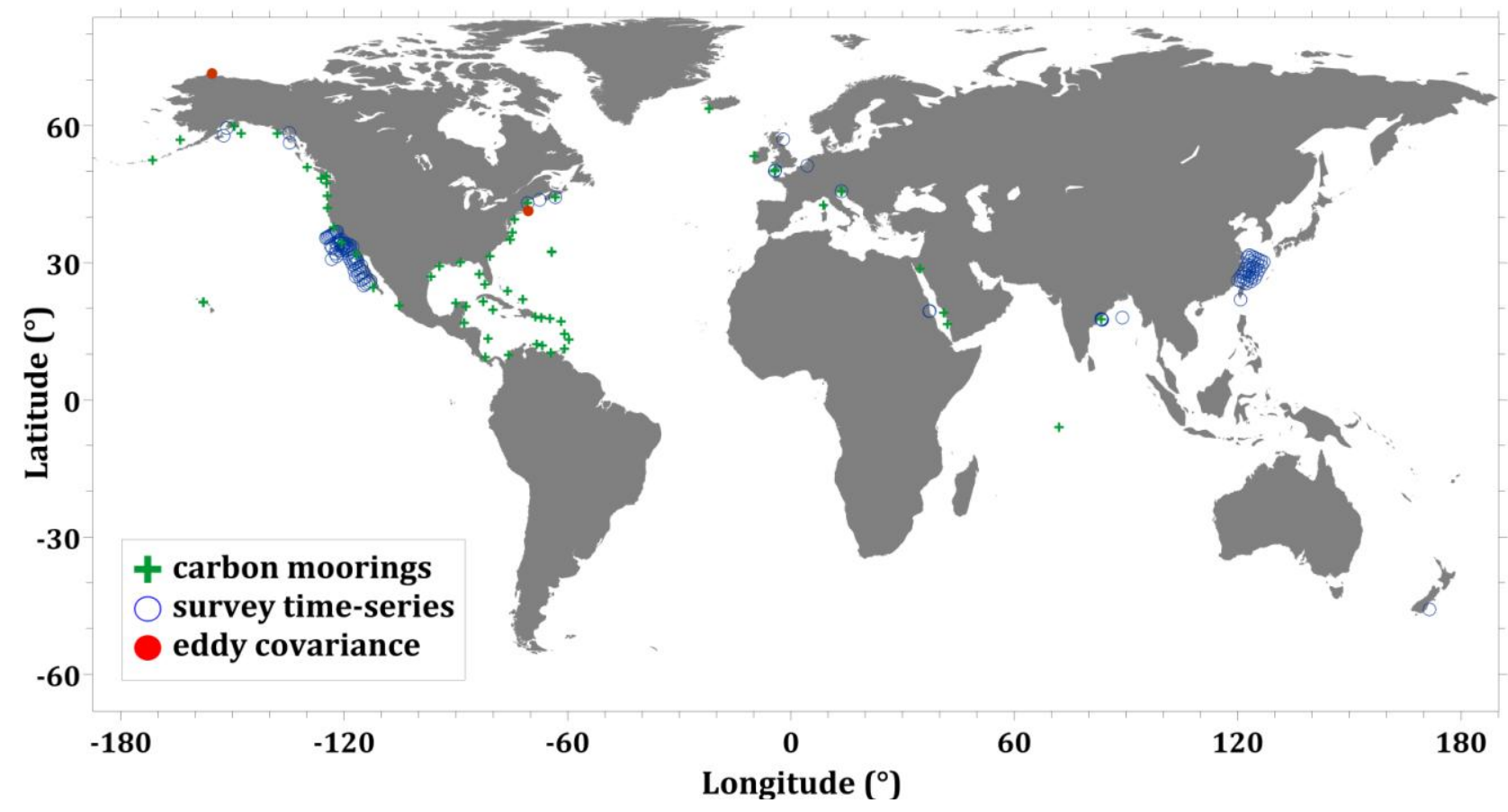

Figure 7 Coastal $\mathrm{CO}_{2}$ moorings (green crosses), time-series (open blue circles), and eddy covariance (solid red circles) stations (details in Tabs. 1 and 2).

about short timescale variability (diurnal to seasonal). The choice of the sites may have to be a compromise between scientific relevance and accessibility from research institutes. In open ocean studies such repeat station long-term data-sets have been extremely valuable (e.g. Wong et al. 1999; Brix et al. 2004; Wakita et al. 2005; Santana-Casiano et al. 2007; Bates 2007). The presently extremely limited number of coastal areas (e.g., Californian Current, Fig. 2) must be increased. A number of long-standing coastal oceanography sampling programs (e.g. California Cooperative Oceanic Fisheries Investigations [CalCOFI], 1949-present; Investigaciones Mexicanas de la Corriente de California [IMECOCAL], 1997present) are presently undertaking to add regular carbon measurements to their repertoire.

\subsection{Large-scale repeat surveys of chemical and biological properties}

The autonomous-automated approaches still need to be complemented by research cruises covering the largest possible area to investigate the vertical and basin-wide distributions of DIC variables and relevant biogeochemical processes (primary production, community respiration, calcification, organic carbon export, ...) (e.g. Thomas et al., 2004, Bozec et al., 2006). Such cruises should be carried out to allow the coverage of the "present day" seasonality and spatial patterns and to place smaller scale studies into broader regional and process-oriented context. These surveys should be repeated in the future to investigate the impact of climate oscillations (NAO (North Atlantic Oscillation), ENSO (El Niño/Southern Oscillation), SAM (Southern Annular Mode), PDO, ...) and/or climate change (changes in circulation, eutrophication, expanding oxygen minimum zones, ocean acidification, ...) on DIC dynamics and overall carbon flows (e.g. Thomas et al., 2007).

\subsection{Ancillary variables to $\mathbf{p C O}_{2}$ and instrumentation improvement and development}

Inclusion of ancillary variables on these automated $\mathrm{pCO}_{2}$ measuring platforms (VOS, moorings, drifters, and autonomous surface vessels) is highly recommended if the data are to be fully interpreted. These ancillary variables are needed to interpret the processes controlling observed $\mathrm{pCO}_{2}$ variations, classify the $\mathrm{pCO}_{2}$ data regionally, and scale $\mathrm{pCO}_{2}$ data. Robust technology is available for variables such as salinity, $\mathrm{O}_{2}$, chlorophyll-a fluorescence, and turbidity, but is still emerging for inorganic nutrients (e.g. Adornato et al. 2010).

Work on $\mathrm{pCO}_{2}$ systems (VOS, moorings, drifters, and autonomous surface vessels) is still needed to make them more robust and to lower the labor overhead. Technology to autonomously and reliably measure inorganic carbon variables other than $\mathrm{pCO}_{2}$ is emerging. Developments of $\mathrm{pH}$ measurements are making good progress (Seidel et al. 2008), but for DIC and total alkalinity (TA), work is at an early stage and needs to be encouraged (e.g. Byrne et al. 2010). 
It is recommended that inter-calibration exercises and technical workshops are carried out to help the development of these technologies.

\subsection{Standard operating procedures (SOP) and quality control (QC) protocols for coastal measurements}

While standard operation procedures (SOP) and quality control (QC) protocols are well established for open ocean $\mathrm{CO}_{2}$ measurements, it is recommended that these SOP and QC protocols be adapted to account for the specific needs of coastal waters from a technical point of view e.g. bio-fouling, turbidity, and the need for fastresponse instruments. From an analytical point of view, new standards for the calibration of $\mathrm{pCO}_{2}, \mathrm{DIC}$ and TA measurements are needed, because typical measurement ranges are beyond those of open oceanic environments, e.g. in estuaries $\mathrm{pCO}_{2}$ values up to $8000 \mathrm{ppm}$ or TA/DIC values up to $4500 \mu$ mol $\mathrm{kg}^{-1}$ have been observed (e.g., Frankignoulle et al. 1996; 1998). In addition, research is needed into suitable constants for computations, in particular for brackish waters (carbonic acid dissociation constants, etc.). This will require laboratory work, technical workshops, and intercalibration exercises

Table 1. Existing, planned, or proposed coastal carbon moorings or eddy covariance towers.

\begin{tabular}{|c|c|c|c|c|c|c|}
\hline Name & $\begin{array}{c}\text { Years of } \\
\text { operation }\end{array}$ & Region & Variables & PI & Institution & Country \\
\hline Akumal & proposed & Caribbean & $\mathrm{T}, \mathrm{S}, \mathrm{O}_{2}, \mathrm{pCO}_{2}, \mathrm{pH}$ & J. Hendee & $\begin{array}{l}\text { Centro Ecological } \\
\text { Akumal }\end{array}$ & \\
\hline Alawai & 2008-present & Pacific (Hawaii) & $\mathrm{T}, \mathrm{S}, \mathrm{O}_{2}, \mathrm{pCO}_{2}$ & E. Di Carlo, C. Sabine & $\begin{array}{l}\text { UH - Coral Reef } \\
\text { Instrumented } \\
\text { Monitoring Platform }\end{array}$ & USA \\
\hline Amukta Pass 1 (Aleutians, Alaska) & 2011 & Gulf of Alaska & $\mathrm{pCO}_{2}, \mathrm{O}_{2}, \mathrm{SSS}, \mathrm{SST}, \mathrm{OA}^{\dagger}$ & P. Stabeno, C. Sabine, S. Alin & PMEL & USA \\
\hline Archipelago Los Roques & proposed & Caribbean & $\mathrm{T}, \mathrm{S}, \mathrm{O}_{2}, \mathrm{pCO}_{2}, \mathrm{pH}$ & J. Hendee & Fundation Los Roques & \\
\hline Arrecife Alacranes & proposed & Caribbean & $\mathrm{T}, \mathrm{S}, \mathrm{O}_{2}, \mathrm{pCO}_{2}, \mathrm{pH}$ & J. Hendee & UNAM & \\
\hline Bahia Magdalena & 2008-present & Pacific (Mexico) & $\mathrm{T}, \mathrm{S}, \mathrm{O}_{2}, \mathrm{pCO}_{2}$ & J.M. Hernandez-Ayon & UABC, CICESE, CICIMAR & $\mathrm{MX}$ \\
\hline Barkley Canyon $\ddagger$ & 2009 & Pacific (N. America) & $\mathrm{T}, \mathrm{S}, \mathrm{O}_{2}, \mathrm{pCO}_{2}$ & D. Ianson, V. Tunnicliffe & Neptune, UBC, IOS & Canada \\
\hline Barrow Point ${ }^{\S}$ & 2009-present & Alaska sea-ice & $\mathrm{CO}_{2}$ fluxes & B. Delille, A.V. Borges & ULG & $\mathrm{BE}$ \\
\hline Biloxi & $\begin{array}{l}\text { 2009-present } \\
\text { (OA in 2010) }\end{array}$ & Gulf of Mexico & $\mathrm{pCO}_{2}, \mathrm{O}_{2}, \mathrm{SSS}, \mathrm{SST}, \mathrm{OA}$ & S. Lohrenz, C. Sabine & USM, NOAA/PMEL & USA \\
\hline Bloody Bay Marine Park & proposed & Caribbean & $\mathrm{T}, \mathrm{S}, \mathrm{O}_{2}, \mathrm{pCO}_{2}, \mathrm{pH}$ & J. Hendee & $\begin{array}{l}\text { Little Cayman Research } \\
\text { Center }\end{array}$ & \\
\hline Bocos del Toro & proposed & Caribbean & $\mathrm{T}, \mathrm{S}, \mathrm{O}_{2}, \mathrm{pCO}_{2}, \mathrm{pH}$ & J. Hendee & Smithsonian & \\
\hline Bonaire NMP & proposed & Caribbean & $\mathrm{T}, \mathrm{S}, \mathrm{O}_{2}, \mathrm{pCO}_{2}, \mathrm{pH}$ & J. Hendee & $\begin{array}{l}\text { Bonaire National } \\
\text { Marine Park }\end{array}$ & \\
\hline Buccoo Marine Park & proposed & Caribbean & $\mathrm{T}, \mathrm{S}, \mathrm{O}_{2}, \mathrm{pCO}_{2}, \mathrm{pH}$ & J. Hendee & USGS & \\
\hline Calvi & 2006-present & Mediterrenean Sea & $\mathrm{pCO}_{2}, \mathrm{O}_{2}, \mathrm{SSS}, \mathrm{SST}$ & A.V. Borges & ULG & BE \\
\hline $\begin{array}{l}\text { Cape Elizabeth (Aberdeen, } \\
\text { Washington) }\end{array}$ & $\begin{array}{l}\text { 2006-present } \\
\text { (OA in 2010) }\end{array}$ & Pacific & $\mathrm{pCO}_{2}, \mathrm{O}_{2}, \mathrm{SSS}, \mathrm{SST}, \mathrm{OA}$ & C. Sabine & NOAA/PMEL & USA \\
\hline Cape Hatteras & 2013 & Atlantic & $\mathrm{pCO}_{2}, \mathrm{O}_{2}, \mathrm{SSS}, \mathrm{SST}, \mathrm{OA}$ & C. Sabine & NOAA/PMEL & USA \\
\hline Chesapeake Bay & 2013 & Atlantic & $\mathrm{pCO}_{2}, \mathrm{O}_{2}, \mathrm{SSS}, \mathrm{SST}, \mathrm{OA}$ & C. Sabine & NOAA/PMEL & USA \\
\hline $\begin{array}{l}\text { Coastal Ocean Biogeochemistry } \\
\text { Observatory (СОВO) }\end{array}$ & 2009 & Bay of Bengal & $\mathrm{T}, \mathrm{S}, \mathrm{O}_{2}, \mathrm{chl}, \mathrm{DIC}, \mathrm{TA}, \mathrm{pCO}_{2}$ & V.V.S.S. Sarma & $\mathrm{NIO}$ & India \\
\hline Corpus Christi, Texas & 2012 & Gulf of Mexico & $\mathrm{pCO}_{2}, \mathrm{O}_{2}, \mathrm{SSS}, \mathrm{SST}, \mathrm{OA}$ & C. Sabine & NOAA/PMEL & USA \\
\hline Crescent Reef & 2010 & Atlantic (Bermuda) & $\mathrm{T}, \mathrm{S}, \mathrm{O}_{2}, \mathrm{pCO}_{2}$ & Andersson, N. Bates, C. Sabine & BIOS, NOAA/PMEL & Bermuda \\
\hline CRIMP & 2005-present & Pacific (Hawaii) & $\mathrm{T}, \mathrm{S}, \mathrm{O}_{2}, \mathrm{pCO}_{2}$ & E. Di Carlo, C. Sabine & $\begin{array}{l}\text { UH - Coral Reef } \\
\text { Instrumented } \\
\text { Monitoring Platform }\end{array}$ & USA \\
\hline Del Este; Punta Cana & proposed & Caribbean & $\mathrm{T}, \mathrm{S}, \mathrm{O}_{2}, \mathrm{pCO}_{2}, \mathrm{pH}$ & J. Hendee & NCORE & \\
\hline Devils Hole & 2009-present & Atlantic (Bermuda) & $\mathrm{T}, \mathrm{S}, \mathrm{O}_{2}$ & Andersson, N. Bates, Aucan & BIOS & Bermuda \\
\hline E1 & 200X-present & English Channel & $\mathrm{T}, \mathrm{S}, \mathrm{O}_{2}$ & $\begin{array}{l}\text { N. Hardman Mountford } \\
\text { (DEFRApH) }\end{array}$ & $\begin{array}{l}\text { Plymouth Marine } \\
\text { Laboratory }\end{array}$ & UK \\
\hline Enrique & 2009-present & Caribbean & $\mathrm{T}, \mathrm{S}, \mathrm{O}_{2}, \mathrm{pCO}_{2}$ & J. Hendee & UPR & \\
\hline Ensenada & 2008-present & Pacific (Mexico) & $\mathrm{T}, \mathrm{S}, \mathrm{O}_{2}, \mathrm{pCO}_{2}$ & J.M. Hernandez-Ayon & UABC, CICESE & $\mathrm{MX}$ \\
\hline Everglades National Park, Florida & 2011 & Gulf of Mexico & $\mathrm{pCO}_{2}, \mathrm{O}_{2}, \mathrm{SSS}, \mathrm{SST}, \mathrm{OA}$ & C. Sabine & NOAA/PMEL & USA \\
\hline Farasan Islands MPA & proposed & Red Sea & $\mathrm{pCO}_{2}, \mathrm{O}_{2}, \mathrm{SSS}, \mathrm{SST}, \mathrm{OA}$ & J. Hendee & NOAA & USA \\
\hline FATE-1 (near Kodiak Island, Alaska) & 2014 & Gulf of Alaska & $\mathrm{pCO}_{2}, \mathrm{O}_{2}, \mathrm{SSS}, \mathrm{SST}, \mathrm{OA}$ & P. Stabeno, C. Sabine, S. Alin & NOAA/PMEL & USA \\
\hline Folkstone Marine Reserve & proposed & Caribbean & $\mathrm{T}, \mathrm{S}, \mathrm{O}_{2}, \mathrm{pCO}_{2}, \mathrm{pH}$ & J. Hendee & UWI & \\
\hline Galveston, Texas & 2013 & Gulf of Mexico & $\mathrm{pCO}_{2}, \mathrm{O}_{2}, \mathrm{SSS}, \mathrm{SST}, \mathrm{OA}$ & C. Sabine & NOAA/PMEL & USA \\
\hline Glovers Reef & proposed & Caribbean & $\mathrm{T}, \mathrm{S}, \mathrm{O}_{2}, \mathrm{pCO}_{2}, \mathrm{pH}$ & J. Hendee & $\begin{array}{l}\text { Wildlife Conservation } \\
\text { Society }\end{array}$ & \\
\hline Gray's Reef & $\begin{array}{l}\text { 2006-present } \\
\text { (OA in 2011) }\end{array}$ & Atlantic & $\mathrm{pCO}_{2}, \mathrm{O}_{2}, \mathrm{SSS}, \mathrm{SST}, \mathrm{OA}$ & W.J. Cai, C. Sabine & UGA, NOAA/PMEL & USA \\
\hline Great Chagos Bank & proposed & Indian & $\mathrm{T}, \mathrm{S}, \mathrm{O}_{2}, \mathrm{pCO}_{2}, \mathrm{pH}$ & J. Hendee, R. Salm & NOAA/TNC & \\
\hline Gulf of Alaska 1 & 2010 & Gulf of Alaska & $\mathrm{T}, \mathrm{S}, \mathrm{O}_{2}, \mathrm{pCO}_{2}, \mathrm{pH}$ & Mathis, Sabine & NOAA/PMEL, UAF & \\
\hline Gulf of Aqaba & proposed & Red Sea & $\mathrm{T}, \mathrm{S}, \mathrm{O}_{2}, \mathrm{pCO}_{2}, \mathrm{pH}$ & J. Hendee & NOAA & \\
\hline
\end{tabular}




\subsection{Achieving global coverage by international coordination and cooperative projects}

While some areas are under-sampled due to the remoteness or harshness of climate (high latitudes), other areas are under-sampled due to lack of regional research capacity, or lack of funding and expertise from existing research institutes, particularly in emerging economy countries. Regarding the latter, it is recommended that cooperative projects are developed to build capacity for local research institutes to deploy, service, and process data from automated $\mathrm{pCO}_{2}$ instrumentation (moorings, drifters). With forecasted changes in ice cover at high latitudes, large changes in

Table 1. Existing, planned, or proposed coastal carbon moorings or eddy covariance towers (Continued).

\begin{tabular}{|c|c|c|c|c|c|c|}
\hline Name & $\begin{array}{c}\text { Years of } \\
\text { operation }\end{array}$ & Region & Variables & PI & Institution & Country \\
\hline Gulf of Maine & $\begin{array}{l}\text { 2006-present } \\
\text { (OA in 2010) }\end{array}$ & Atlantic & $\mathrm{pCO}_{2}, \mathrm{O}_{2}, \mathrm{SSS}, \mathrm{SST}, \mathrm{OA}$ & $\begin{array}{l}\text { J. Salisbury, D. Vandemark, C. } \\
\text { Sabine }\end{array}$ & UNH, NOAA/PMEL & USA \\
\hline Hog Reef & 2010 & Atlantic (Bermuda) & $\mathrm{T}, \mathrm{S}, \mathrm{O}_{2}, \mathrm{pCO}_{2}$ & Andersson, Bates \& Sabine & BIOS, NOAA/PMEL & \\
\hline $\begin{array}{l}\text { Iceland shelf } \\
\text { Isle of Pines }\end{array}$ & $\begin{array}{l}2010 \\
\text { proposed }\end{array}$ & $\begin{array}{l}\text { Iceland shelf } \\
\text { Caribbean }\end{array}$ & $\begin{array}{l}\mathrm{pCO} 2, \mathrm{SSS}, \mathrm{SST}, \mathrm{O} 2 \\
\mathrm{~T}, \mathrm{~S}, \mathrm{O}_{2}, \mathrm{pCO}_{2}, \mathrm{pH}\end{array}$ & $\begin{array}{l}\text { J. Ólafsson } \\
\text { J. Hendee }\end{array}$ & $\begin{array}{l}\text { HAFRO } \\
\text { Inst. Invest.Ocean. }\end{array}$ & IS \\
\hline Kilo Nalu & 2008-present & Pacific (Hawaii) & $\mathrm{T}, \mathrm{S}, \mathrm{O}_{2}, \mathrm{pCO}_{2}$ & E. Di Carlo, C. Sabine & $\begin{array}{l}\text { UH - Coral Reef } \\
\text { Instrumented } \\
\text { Monitoring Platform }\end{array}$ & USA \\
\hline L4 & 2009 & English Channel & $\mathrm{T}, \mathrm{S}, \mathrm{O} 2$ & $\begin{array}{l}\text { N. Hardman Mountford } \\
\text { (DEFRApH) }\end{array}$ & $\begin{array}{l}\text { Plymouth Marine } \\
\text { Laboratory }\end{array}$ & UK \\
\hline Lee Stocking Island & proposed & Caribbean & $\mathrm{T}, \mathrm{S}, \mathrm{O}_{2}, \mathrm{pCO}_{2}, \mathrm{pH}$ & J. Hendee & $\begin{array}{l}\text { Perry Institute for } \\
\text { Marine Science }\end{array}$ & \\
\hline LEO-15 & 2012 & Atlantic & $\mathrm{pCO}_{2}, \mathrm{O}_{2}, \mathrm{SSS}, \mathrm{SST}, \mathrm{OA}$ & C. Sabine & NOAA/PMEL & USA \\
\hline M2 & 2014 & Bering Sea & $\mathrm{pCO}_{2}, \mathrm{O}_{2}, \mathrm{SSS}, \mathrm{SST}, \mathrm{OA}$ & P. Stabeno, C. Sabine, S. Alin & NOAA/PMEL & USA \\
\hline Mace Head & 2008-present & Atlantic (NW Europe) & $\mathrm{T}, \mathrm{S}, \mathrm{O}_{2}, \mathrm{pCO}_{2}$ & Ward, O'Dowd, Cave & CCAPS/ECI, NUI & Ireland \\
\hline $\begin{array}{l}\text { Martha's Vineyard Coastal } \\
\text { Observatory }\end{array}$ & 2002-present & U.S. East Coast & $\mathrm{CO}_{2}$ fluxes & W. McGillis & LDEO, WHOI & USA \\
\hline Mochima & proposed & Caribbean & $\mathrm{T}, \mathrm{S}, \mathrm{O}_{2}, \mathrm{pCO}_{2}, \mathrm{pH}$ & J. Hendee & Univ. Oriente & \\
\hline NANOOS (LaPush, Washington) & 2010 & Pacific (N. America) & $\begin{array}{l}\mathrm{T}, \mathrm{S}, \mathrm{O}_{2}, \mathrm{CO}_{2}, \mathrm{ADCP} \text {, fluorescence, } \\
\text { turbidity, } \mathrm{NO}_{3}\end{array}$ & Newton, Sabine, Devol, Alford & $\begin{array}{l}\text { UW, NANOOS, } \\
\text { NOAA/PMEL }\end{array}$ & USA \\
\hline North Sound & proposed & Caribbean & $\mathrm{T}, \mathrm{S}, \mathrm{O}_{2}, \mathrm{pCO}_{2}, \mathrm{pH}$ & J. Hendee & UM, TAMU & \\
\hline off San Francisco Bay & 2013 & Pacific & $\mathrm{pCO}_{2}, \mathrm{O}_{2}, \mathrm{SSS}, \mathrm{SST}, \mathrm{OA}$ & C. Sabine, S. Alin & NOAA/PMEL & USA \\
\hline PALOMA & planned & $\begin{array}{l}\text { North Adriatic - } \\
\text { Mediterranean } \\
\text { (Europe) }\end{array}$ & $\mathrm{T}, \mathrm{S}, \mathrm{O}_{2}, \mathrm{pCO}_{2}, \mathrm{pH}$ & A. Luchetta & $\begin{array}{l}\text { CNR (National Council } \\
\text { of Research) -ISMAR } \\
\text { (Marine Sciences } \\
\text { Institute) }\end{array}$ & IT \\
\hline Point Conception, California & 2012 & Pacific & $\mathrm{pCO}_{2}, \mathrm{O}_{2}, \mathrm{SSS}, \mathrm{SST}, \mathrm{OA}$ & V. Fabry, C. Sabine & CSUSM, NOAA/PMEL & USA \\
\hline Poseidon E1-M3A & $\begin{array}{l}2000-\text { present } \\
\left(\mathrm{pCO}_{2} \text { in 2009) }\right.\end{array}$ & Cretan sea & $\begin{array}{l}\mathrm{pCO}_{2}, \mathrm{~T}, \mathrm{~S} \text {, chl, turbidity, } \mathrm{NO}_{3}, \\
\text { PAR, } \mathrm{O}_{2} \text {, currents }\end{array}$ & G. Petihakis, E. Krasakopoulou & HCMR & GR \\
\hline Puerto Vallarta & 2010 & Pacific (Mexico) & $\mathrm{T}, \mathrm{S}, \mathrm{O}_{2}, \mathrm{pCO}_{2}$ & J.M. Hernandez-Ayon & UABC, CICESE, UAG & $\mathrm{MX}$ \\
\hline Salt River Canyon (NPS) & proposed & Caribbean & $\mathrm{T}, \mathrm{S}, \mathrm{O}_{2}, \mathrm{pCO}_{2}, \mathrm{pH}$ & J. Hendee & UVI & \\
\hline San Bernardo & proposed & Caribbean & $\mathrm{T}, \mathrm{S}, \mathrm{O}_{2}, \mathrm{pCO}_{2}, \mathrm{pH}$ & J. Hendee & Invesmart & \\
\hline Scotian Shelf & 2006-present & Scotian Shelf & $\mathrm{pCO}_{2}$, SSS, SST, wind, air T, chl & H. Thomas & DAL & CA \\
\hline Seaflower Biosphere Reserve & proposed & Caribbean & $\mathrm{T}, \mathrm{S}, \mathrm{O}_{2}, \mathrm{pCO}_{2}, \mathrm{pH}$ & J. Hendee & Coralina (NGO) & \\
\hline South Island area & proposed & Caribbean & $\mathrm{T}, \mathrm{S}, \mathrm{O}_{2}, \mathrm{pCO}_{2}, \mathrm{pH}$ & J. Hendee & IFREMER/IRD & \\
\hline Stonewall Banks (Newport, Oregon) & 2014 & Pacific & $\mathrm{pCO}_{2}, \mathrm{O}_{2}, \mathrm{SSS}, \mathrm{SST}, \mathrm{OA}$ & B. Hales, C. Sabine, S. Alin & OSU, NOAA/PMEL & USA \\
\hline Tampa-St. Petersburg, Florida & 2012 & Gulf of Mexico & $\mathrm{pCO}_{2}, \mathrm{O}_{2}, \mathrm{SSS}, \mathrm{SST}, \mathrm{OA}$ & C. Sabine & NOAA/PMEL & USA \\
\hline Three Mary Cays & proposed & Caribbean & $\mathrm{T}, \mathrm{S}, \mathrm{O}_{2}, \mathrm{pCO}_{2}, \mathrm{pH}$ & J. Hendee & $\begin{array}{l}\text { Turks and Caicos } \\
\text { School for Field Studies }\end{array}$ & \\
\hline Trinidad Head & $\begin{array}{l}2010 \text { (OA in } \\
2011)\end{array}$ & Pacific & $\mathrm{pCO}_{2}, \mathrm{O}_{2}, \mathrm{SSS}, \mathrm{SST}, \mathrm{OA}$ & V. Fabry, C. Sabine & CSUSM, NOAA/PMEL & USA \\
\hline Umm al-Qamari Islands MPA & proposed & Red Sea & $\mathrm{pCO}_{2}, \mathrm{O}_{2}, \mathrm{SSS}, \mathrm{SST}, \mathrm{OA}$ & J. J. Hendee & NOAA & USA \\
\hline Vancouver-Queen Charlotte Islands & 2012 & Pacific & $\mathrm{pCO}_{2}, \mathrm{O}_{2}, \mathrm{SSS}, \mathrm{SST}, \mathrm{OA}$ & B. Hales, S. Alin, C. Sabine & OSU, NOAA/PMEL & USA \\
\hline VIDA & $\begin{array}{l}\text { 2002-present } \\
\left(\mathrm{pCO}_{2} \text { in 2007, } \mathrm{O}_{2}\right. \\
+\mathrm{chl} \text { in 2008) }\end{array}$ & Gulf of Trieste & $\begin{array}{l}\mathrm{SST}, \mathrm{SSS} \text {, wind, air temp, } \\
\text { humidity, } \mathrm{pCO}_{2}, \mathrm{O}_{2} \text {, chl, currents, } \\
\text { waves, bottom T }\end{array}$ & V. Malacic, D.Turk & NIB & SL \\
\hline Yakutat-Juneau, Alaska & 2013 & Gulf of Alaska & $\mathrm{pCO}_{2}, \mathrm{O}_{2}, \mathrm{SSS}, \mathrm{SST}, \mathrm{OA}$ & B. Hales, S. Alin, C. Sabine & OSU, NOAA/PMEL & USA \\
\hline
\end{tabular}

at-Juneau, Alaska

2013

Gulf of Alaska

$\mathrm{CO}_{2}, \mathrm{O}_{2}$, SSS, SST, OA

B. Hales, S. Alin, C. Sabine OSU, NOAA/PMEL 
ocean uptake of atmospheric $\mathrm{CO}_{2}$ are predicted, which makes instrumentation to record changes in coastal ocean uptake of atmospheric $\mathrm{CO}_{2}$ are predicted, which makes instrumentation to record changes in coastal carbon fluxes at high latitudes especially desirable.

Furthermore, it would be useful to have an international organization that could help coordinate this coastal carbon research within their exclusive economic zones (EEZ) and the facilitation of data sharing. Some countries legally restrict the rights of scientists to openly share data collected within their EEZs for security reasons. Data sharing and permitting issues stand to interfere with important coastal carbon research initiatives at a critical time when national and international research communities should be planning

Table 2. Coastal carbon time-series sampling stations.

\begin{tabular}{|c|c|c|c|c|c|}
\hline Name & Years of operation & Region & Variables & PI & Institution \\
\hline$\overline{\text { Baranof Island } \dagger}$ & 2010 & Gulf of Alaska & $\mathrm{T}, \mathrm{S}, \mathrm{DIC}, \mathrm{TA}$, nutrients & Carls, Sigler & NOAA/AFSC \\
\hline $\begin{array}{l}\text { Bay of Bengal Ocean } \\
\text { Timeseries Station (BOTS) }\end{array}$ & 2010 & Bay of Bengal & $\mathrm{T}, \mathrm{S}, \mathrm{O}_{2}, \mathrm{chl}, \mathrm{DIC}, \mathrm{TA}, \mathrm{pCO}_{2}$ & V.V.S.S. Sarma & NIO \\
\hline CalCOFI & $\begin{array}{l}\text { 1949-present (hydrography, } \\
\text { fisheries), 2008-present } \\
\text { (carbon) }\end{array}$ & Central and southern California & $\mathrm{T}, \mathrm{S}, \mathrm{O}_{2}, \mathrm{CO}_{2}, \mathrm{TA}, \mathrm{DIC}, \mathrm{chl}$ & $\begin{array}{l}\text { A. Dickson (for inorganic } \\
\text { carbon) }\end{array}$ & CalCOFI \\
\hline $\begin{array}{l}\text { Coastal time-series } \\
\text { observations }\end{array}$ & $\begin{array}{l}\text { 2007-present (carbon } \\
\text { 2008-present) }\end{array}$ & Coastal Bay of Bengal & $\mathrm{T}, \mathrm{S}$, nutrients, $\mathrm{TA}, \mathrm{pH}, \mathrm{DIC}, \mathrm{chl}$ & V.V.S.S. Sarma & NIO \\
\hline E1 & $2008-2010$ & English Channel & $\mathrm{T}, \mathrm{S}, \mathrm{O}_{2}, \mathrm{CO}_{2}, \mathrm{pH}, \mathrm{TA}, \mathrm{DIC}$ & $\begin{array}{l}\text { N. Hardman Mountford } \\
\text { (DEFRApH) }\end{array}$ & $\begin{array}{l}\text { Plymouth Marine } \\
\text { Laboratory }\end{array}$ \\
\hline GNATS & 1998-present & Gulf of Maine & $\begin{array}{l}\text { T, S, nutrients, carbon fixation, } \\
\text { phytoplankton biomass, POC, PIC, } \\
\text { chl, biogenic silica, inherent and } \\
\text { apparent optical properties }\end{array}$ & W. Balch & $\begin{array}{l}\text { Bigelow Laboratory } \\
\text { for Ocean Sciences }\end{array}$ \\
\hline IMECOCAL & $\begin{array}{l}\text { 1997-present (hydrography), } \\
\text { 2006-present (carbon) }\end{array}$ & Baja California coast & $\begin{array}{l}\mathrm{T}, \mathrm{S}, \mathrm{O}_{2}, \text { chl, nutrients, }{ }^{14} \mathrm{C} \\
\text { production, zooplankton }\end{array}$ & $\begin{array}{l}\text { M. Hernandez-Ayon (for } \\
\text { inorganic carbon) }\end{array}$ & IMECOCAL \\
\hline Kasitsna Bay ${ }^{\dagger}$ & 2010 & Gulf of Alaska & $\mathrm{T}, \mathrm{S}, \mathrm{DIC}, \mathrm{TA}$, nutrients & Holdereid, Sigler & NOAA/AFSC \\
\hline Kodiak ${ }^{+}$ & 2010 & Gulf of Alaska & $\mathrm{T}, \mathrm{S}, \mathrm{DIC}, \mathrm{TA}$, nutrients & Foy, Sigler & NOAA/AFSC \\
\hline L4 & 2008-2010 & English Channel & $\mathrm{T}, \mathrm{S}, \mathrm{O}_{2}, \mathrm{CO}_{2}, \mathrm{pH}, \mathrm{TA}, \mathrm{DIC}$ & $\begin{array}{l}\text { N. Hardman Mountford } \\
\text { (DEFRApH) }\end{array}$ & $\begin{array}{l}\text { Plymouth Marine } \\
\text { Laboratory }\end{array}$ \\
\hline Lena Point ${ }^{\dagger}$ & 2010 & Gulf of Alaska & $\mathrm{T}, \mathrm{S}, \mathrm{DIC}, \mathrm{TA}$, nutrients & Carls, Sigler & NOAA/AFSC \\
\hline LORECS & 2003-present & East China Sea & $\begin{array}{l}\mathrm{pCO}_{2}, \mathrm{TA}, \mathrm{DIC}, \mathrm{O}_{2} \text {, nutrients, chl, PP, } \\
\text { SST, SSS }\end{array}$ & $\begin{array}{l}\text { G.C. Gong, C.M. Tseng, } \\
\text { W.C. Chou }\end{array}$ & NTOU/NTU \\
\hline Monterey Bay transect & 2003-present & Monterey Bay, California & $\mathrm{T}, \mathrm{S}, \mathrm{O}_{2}, \mathrm{CO}_{2}, \mathrm{TA}, \mathrm{DIC}$ & F. Chavez & MBARI \\
\hline Munida time series & 1998-present & south east coast of New Zealand & $\mathrm{pCO}_{2}, \mathrm{TA}$, nutrients, chl, SST, SSS & K. Currie & NIWA \\
\hline Nanwan Bay & 1986-present (4 times/yr) & South China Sea & $\mathrm{pH}, \mathrm{S}, \mathrm{T}, \mathrm{O}_{2}$, nutrients, chl & C.T.A. Chen & NSYSU \\
\hline PALOMA & 2008-present & $\begin{array}{l}\text { North Adriatic - Mediterranean } \\
\text { (Europe) }\end{array}$ & $\mathrm{T}, \mathrm{S}, \mathrm{O}_{2}, \mathrm{pH}, \mathrm{TA}$, nutrients & A. Luchetta & $\begin{array}{l}\text { CNR (National Council } \\
\text { of Research) -ISMAR } \\
\text { (Marine Sciences } \\
\text { Institute) }\end{array}$ \\
\hline Port Sudan & 2009-2012 & Red Sea & $\mathrm{T}, \mathrm{S}, \mathrm{O}_{2}, \mathrm{DIC}, \mathrm{TA}$ & $\begin{array}{l}\text { I. Skjelvan, A. Omar, A. } \\
\text { Elhag }\end{array}$ & $\begin{array}{l}\text { UiB, Red Sea } \\
\text { University }\end{array}$ \\
\hline Prince Madog & 2008-2010 & Irish Sea & SSS, SST, F, O ${ }_{2}, \mathrm{TA}, \mathrm{DIC}, \mathrm{NO}_{3}$ & J. Howarth (DEFRApH) & POL \\
\hline Scotian Shelf & 2006-present & Scotian Shelf & DIC, TA, $\mathrm{pCO}_{2}$ & H. Thomas & DAL \\
\hline Ste Anna & 2003-present & Upper Scheldt estuary & $\mathrm{pCO}_{2}, \mathrm{SSS}, \mathrm{SST}$ & A.V. Borges & ULG \\
\hline Stonehaven & 2008-2010 & North Sea & SSS, SST, $\mathrm{NO}_{3}, \mathrm{TA}, \mathrm{DIC}$ & S. Hay (DEFRApH) & FRS \\
\hline UNH Coastal Marine Lab & 2006,2008 , resume $7 / 2009$ & Gulf of Maine, Piscataquis River & $\mathrm{pCO}_{2}, \mathrm{SSS}, \mathrm{SST}$ & J. Salisbury, D. Vandemar & UNH \\
\hline
\end{tabular}

† Sampling at these stations will be from seawater supplies piped into NOAA research labs from the adjacent coastal water bodies.

carbon observational system. Major issues that could be facilitated by this body include obtaining appropriate permissions from various countries to facilitate coastal

Contemporaneous efforts to implement the coastal GOOS (Global Ocean Observing System) module could be very synergistic with coastal carbon observational efforts, as the sharing of resources and observational capacity among communities should be mutually for active monitoring and data sharing efforts related to coastal $\mathrm{CO}_{2}$ synthesis, ocean acidification early warning networks, and so on.

beneficial. The coastal GOOS community also seems to be further along with developing the types of international research facilitation strategies that will be needed for successful international coastal carbon syntheses and OA observational networks (e.g. Malone et al. 2010). 
Table 3. Underway carbon observing systems deployed or planned for deployment in coastal waters globally.

\begin{tabular}{|c|c|c|c|c|c|}
\hline Ship or Transect Name & $\begin{array}{c}\text { Type of } \\
\text { platform }\end{array}$ & $\begin{array}{c}\text { Years of } \\
\text { operation }\end{array}$ & Region & Variables & PI \\
\hline Belgica & VOS line & 2002-present & North Sea, English Channel, Celtic Sea & $\mathrm{pCO}_{2}, \mathrm{SST}, \mathrm{SSS}$ & A.V. Borges \\
\hline Bergen-Amsterdam & Vos line & 2005-present & North Sea & $\mathrm{pCO}_{2}, \mathrm{SST}, \mathrm{SSS}$ & A. Omar, T. Johannessen \\
\hline Explorer of the Seas & Cruise ship & $2002-2007$ & U.S. East Coast, Caribbean & $\mathrm{pCO}_{2}, \mathrm{SST}, \mathrm{SSS}, \mathrm{chl}$ & R. Castle, B. Huss, R.Wanninkhof \\
\hline Finnmaid & VOS line & 2003-present & Baltic Sea & $\mathrm{pCO}_{2}, \mathrm{O}_{2}, \mathrm{SSS}, \mathrm{SST}$ & B. Schneider \\
\hline James Clark Ross & Research ship & 2006-present & Southern Ocean and Patagonian shelves & $\begin{array}{l}\mathrm{pCO}_{2}, \mathrm{O}_{2}, \mathrm{SSS}, \mathrm{SST} \\
\text { fluorescence, PAR }\end{array}$ & N. Hardman-Mountford \\
\hline Las Cuevas & Tanker & 2009 & Gulf of Mexico & $\mathrm{pCO}_{2}, \mathrm{SST}, \mathrm{SSS}$ & $\begin{array}{l}\text { D. Pierrot, K. Sullivan, R. } \\
\text { Wanninkhof }\end{array}$ \\
\hline LORECS & Research ship & 2003-present & East China Sea & $\begin{array}{l}\mathrm{pCO}_{2}, \mathrm{TA}, \mathrm{DIC}, \mathrm{O}_{2} \\
\text { nutrients, chl, } \mathrm{PP}, \mathrm{SST} \text {, SSS }\end{array}$ & \\
\hline Luctor & VOS line & 2008-present & whole Scheldt estuary & $\mathrm{pCO}_{2}, \mathrm{SST}, \mathrm{SSS}$ & A.V. Borges \\
\hline NOAA ship David Starr Jordan & Research ship & $2006-2008$ & U.S. West Coast, Central America & $\mathrm{pCO}_{2}, \mathrm{O}_{2}, \mathrm{SSS}, \mathrm{SST}$ & S. Alin, R. Feely \\
\hline NOAA ship Gordon Gunther & Research ship & 2007-present & Northern Gulf of Mexico & $\mathrm{pCO}_{2}, \mathrm{SST}, \mathrm{SSS}$ & D. Pierrot, R. Wanninkhof \\
\hline NOAA ship McArthur II & Research ship & 2006-present & U.S. West Coast, Central America & $\mathrm{pCO}_{2}, \mathrm{O}_{2}, \mathrm{SSS}, \mathrm{SST}$ & S. Alin, R. Feely \\
\hline NOAA ship Miller Freeman & Research ship & 2009-present & U.S. West Coast, Gulf of Alaska & $\mathrm{pCO}_{2}, \mathrm{O}_{2}, \mathrm{SSS}, \mathrm{SST}$ & S. Alin, R. Feely \\
\hline NOAA ship Oscar Dyson & Research ship & 2010 & U.S. West Coast, Gulf of Alaska, Bering Sea & $\mathrm{pCO}_{2}, \mathrm{O}_{2}, \mathrm{SSS}, \mathrm{SST}$ & S. Alin, R. Feely \\
\hline NOAA ship Ronald H. Brown & Research ship & since 1998 & U.S. Gulf of Mexico, East, West coasts & $\mathrm{pCO}_{2}, \mathrm{SST}, \mathrm{SSS}, \mathrm{chl}$ & $\begin{array}{l}\text { R. Castle, K. Sullivan, } \\
\text { R.Wanninkhof }\end{array}$ \\
\hline Nuka Arctica & VOS line & 2005-present & $\begin{array}{l}\text { North Sea, Iceland Basin, Irminger Sea, West } \\
\text { Greenland }\end{array}$ & $\mathrm{pCO}_{2}, \mathrm{SST}, \mathrm{SSS}$ & $\begin{array}{l}\text { A. Olsen, T. Johannessen, G. } \\
\text { Reverdin (SSS) }\end{array}$ \\
\hline Oleander & VOS line & $\begin{array}{l}\text { 2006, 2009- } \\
\text { present }\end{array}$ & New Jersey Coast, Bermuda Platform & $\mathrm{pCO}_{2}, \mathrm{SST}$ & N.R. Bates, R. Wanninkhof \\
\hline Plymouth Quest & Research ship & 2005-present & Western English Channel & $\begin{array}{l}\mathrm{pCO}_{2}, \mathrm{O}_{2}, \mathrm{SSS}, \mathrm{SST} \\
\text { fluorescence, } \\
\text { transmissometer }\end{array}$ & N. Hardman-Mountford \\
\hline Pride of Bilbao & VOS line & 2005-present & English Channel, Celtic Sea, Bay of Biscay & SSS, SST, F, O ${ }_{2}$, TA, DIC & D.J. Hydes (since 2008 DEFRApH) \\
\hline Prince Madog & Research ship & 2006-present & Irish Sea & $\mathrm{pCO}_{2}, \mathrm{O}_{2}, \mathrm{SSS}, \mathrm{SST}$ & N. Hardman-Mountford \\
\hline Rickers & Research ship & 2008-present & Gulf of Alaska, North American West Coast & $\mathrm{pCO}_{2}, \mathrm{SSS}, \mathrm{SST}$ & B. Hales, W. Evans \\
\hline Simon Stevin & VOS line & 2011 & Belgian coast & $\mathrm{pCO}_{2}, \mathrm{SST}, \mathrm{SSS}$ & A.V. Borges \\
\hline TRANCOS & VOS line & 2009-present & Iberian coast & $\mathrm{pCO}_{2}, \mathrm{O}_{2}, \mathrm{SSS}, \mathrm{SST}$ & A. F. Ríos \& C. Pelejero \\
\hline VIBRA & Vos line & 2010 & Northeastern coast of South America & $\mathrm{pCO}_{2}, \mathrm{O}_{2}, \mathrm{SSS}, \mathrm{SST}$ & A. F. Ríos \\
\hline $\begin{array}{l}\text { VOS-Ocean Biogeochemistry } \\
\text { Observatory (VOBO) }\end{array}$ & Research ship & 2010 (proposed) & Northern Indian Ocean & $\mathrm{SST}, \mathrm{SSS}, \mathrm{O}_{2}, \mathrm{chl}, \mathrm{pCO}_{2}$ & VVSS Sarma \\
\hline Walton Smith & Research ship & 2008-present & U.S. East Coast, Caribbean & $\mathrm{pCO}_{2}, \mathrm{SST}, \mathrm{SSS}$ & F. Millero \\
\hline
\end{tabular}

\section{DATA MANAGEMENT, SYNTHESIS, AND PRODUCT DEVELOPMENT}

\subsection{Data Management and Products}

Data banking in international, public, quality checked (Carbon Dioxide Information Analysis Center CDIAC) and uniform format (Surface Ocean $\mathrm{CO}_{2}$ Atlas - SOCAT) databases on coastal carbon need to be further developed, with funding allocated for their longterm maintenance and updating. Over the long-term, the related data synthesis will facilitate more robust air-sea $\mathrm{CO}_{2}$ flux estimates in coastal environments, improve our knowledge of spatial and temporal (daily, seasonal, inter-annual, decadal) variations in air-sea $\mathrm{CO}_{2}$ exchange, and equip the international research and monitoring communities with critical tools for anticipating and adapting to anthropogenic carbon cycle perturbations (warming, hypoxia, ocean acidification, eutrophication...).

\subsection{Joint Synthesis Activities}

Community data synthesis needs to be carried out at local, regional and global scales. The first coastal ocean $\mathrm{CO}_{2}$ climatology for North America recently concluded that North American continental margins to a distance

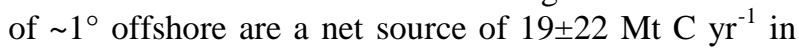
$\mathrm{CO}_{2}$, based on a database of half a million data points (Chavez et al. 2007). Through this effort, substantial sampling gaps were identified in regions interpreted to be large sources or sinks (Gulf of Mexico and Gulf of Alaska, respectively). It is recommended that procedures to achieve a global climatology of coastal air-sea $\mathrm{CO}_{2}$ fluxes be discussed within the scientific community, and a first version of such climatology be achieved in near future, as initiated in the framework of SOCAT. The first global coastal $\mathrm{CO}_{2}$ climatology is likely to identify significant sampling gaps that will help target future observational efforts, as they have in North American waters. Efforts toward model-data 
comparisons of coastal carbon fluxes for North American coastal oceans have been initiated by the North American Carbon Program and are encouraged in other regions as well. Synthesis of data should be carried out with a variety of approaches such as remote sensing and biogeochemical modeling.

\subsection{Forecast tools}

Further work is needed in developing methods using historical $\mathrm{CO}_{2}$ and related chemical data to generate seasonal $\mathrm{CO}_{2}$ flux maps and proxy indicators for ocean acidification conditions that will allow researchers to generate forecasting tools useful for fisheries and resource management professionals.

\section{REFERENCES}

1. Abril G., M. Nogueira, H. Etcheber, G. Cabecadas, E. Lemaire \& M.J. Brogueira (2002) Behaviour of Organic Carbon in Nine Contrasting European Estuaries, Estuarine, Coastal and Shelf Science, 54: 241-262, doi:10.1006/ecss.2001.0844.

2. Adornato, L. \& Co-Authors (2010). "In Situ Nutrient Sensors for Ocean Observing Systems" in these proceedings (Vol. 2), doi:10.5270/OceanObs09.cwp.01.

3. Allen, J. Icarus; Aiken, James; Anderson, Thomas R.; Buitenhuis, Erik; Cornell, Sarah; Geider, Richard J., Haines, Keith; Hirata, Takafumi, Holt, Jason; Le Quéré, Corinne; Hardman-Mountford, Nicholas; Ross, Oliver N.; Sinha, Bablu; While, James. 2010 Marine ecosystem models for earth systems applications: The MarQUEST experience. Journal of Marine System, 81 (1-2). 19-33. 10.1016/j.jmarsys.2009.12.017.

4. Alongi, D. M. 2002. Present state and future of the world's mangrove forests. Environmental Conservation 29(3):331-349.

5. Andersson, A. J. and F. T. Mackenzie. 2004. Shallowwater oceans: a source or a sink of atmospheric $\mathrm{CO} 2$ ? Frontiers in Ecology and the Environment 2(7):348353.

6. Bakun, A. 1990. Global climate change and intensification of coastal ocean upwelling. Science 247(4939):198201.

7. Balch, W. M., H. R. Gordon, B. C. Bowler, D. T. Drapeau, and E. S. Booth. 2005. Calcium carbonate measurements in the surface global ocean based on Moderate-Resolution Imaging Spectroradiometer data, J. Geophys. Res. 110 : C07001, doi:10.1029/2004JC002560.

8. Bates, N. R. 2002. Seasonal variability of the effect of coral reefs on seawater $\mathrm{CO}_{2}$ and air-sea $\mathrm{CO}_{2}$ exchange, Limnology and Oceanography 47(1):43-52.

9. Bates, N. R. (2007), Interannual variability of the oceanic $\mathrm{CO} 2$ sink in the subtropical gyre of the North Atlantic
Ocean over the last 2 decades, J. Geophys. Res., 112 , C09013, doi:10.1029/2006JC003759.

10. Bograd, S. J., C. G. Castro, E. Di Lorenzo, D. M. Palacios, H. Bailey, W. Gilly, and F. P. Chavez (2008), Oxygen declines and the shoaling of the hypoxic boundary in the California Current, Geophys. Res. Lett., 35, L12607, doi:10.1029/2008GL034185.

11. Bopp, L., C. Le Quéré, M. Heimann, A. C. Manning, and P. Monfray (2002), Climate-induced oceanic oxygen fluxes: Implications for the contemporary carbon budget, Global Biogeochem. Cycles, 16(2), 1022, doi:10.1029/2001GB001445.

12. Borges, A. V. and M. Frankignoulle (2002a)

Distribution of surface carbon dioxide and air-sea exchange in the upwelling system off the Galician coast. Global Biogeochemical Cycles 16(2), 1020, doi:10.1029/2000GB001385.

13. Borges A. V. \& M. Frankignoulle (2002b) Aspects of dissolved inorganic carbon dynamics in the upwelling system off the Galician coast, Journal of Marine Systems, 32: 181-198, doi:10.1016/S0924-7963(02)00031-3.

14. Borges A. V. \& M. Frankignoulle (2002c) Distribution and air-water exchange of carbon dioxide in the Scheldt plume off the Belgian coast, Biogeochemistry, 59 (1-2): 41-67, doi:10.1023/A:1015517428985.

15. Borges A.V. (2005) Do we have enough pieces of the jigsaw to integrate $\mathrm{CO} 2$ fluxes in the Coastal Ocean? Estuaries, 28(1):3-27.

16. Borges A.V., B. Delille \& M. Frankignoulle (2005) Budgeting sinks and sources of $\mathrm{CO} 2$ in the coastal ocean: Diversity of ecosystems counts, Geophysical Research Letters, 32, L14601, doi:10.1029/2005GL023053.

17. Borges A.V., B. Tilbrook, N. Metzl, A. Lenton \& B Delille (2008b) Inter-annual variability of the carbon dioxide oceanic sink south of Tasmania, Biogeosciences, 5, 141-155.

18. Borges A.V., K. Ruddick, L.-S. Schiettecatte \& B. Delille (2008a) Net ecosystem production and carbon dioxide fluxes in the Scheldt estuarine plume, $B M C$ Ecology, 8:15, doi:10.1186/1472-6785-8-15.

19. Bouillon S., M. Frankignoulle, F. Dehairs, B. Velimirov, A. Eiler, G. Abril, H. Etcheber and A.V. Borges (2003) Inorganic and organic carbon biogeochemistry in the Gautami Godavari estuary (Andhra Pradesh, India) during pre-monsoon: the local impact of extensive mangrove forests, Global Biogeochemical Cycles, 17 (No. 4): 1114, doi:10.1029/2002GB002026.

20. Bozec, Y., H. Thomas, L.-S. Schiettecatte, A.V. Borges, K. Elkalay and H.J.W. de Baar (2006). Assessment of the processes controlling the seasonal variations of dissolved inorganic carbon in the North Sea, Limnol. and Oceanography, 51, 2746-2762. 
21. Brix, H., N. Gruber, and C. D. Keeling (2004), Interannual variability of the upper ocean carbon cycle at station ALOHA near Hawaii, Global Biogeochem. Cycles, 18, GB4019, doi:10.1029/2004GB002245.

22. Byrne, R. \& Co-Authors (2010). "Sensors and Systems for In Situ Observations of Marine Carbon Dioxide System Variables" in these proceedings (Vol. 2), doi:10.5270/OceanObs09.cwp.13.

23. Cai W.-J., Dai, M.H., Wang, Y.C., 2006. Air-sea exchange of carbon dioxide in ocean margins: A province-based synthesis. Geophysical Research Letters, 33, L12603, doi:10.1029/2006GL026219.

24. Cai, W.-J., Wang, Z.A., Wang, Y., 2003. The role of marsh-dominated heterotrophic continental margins in transport of $\mathrm{CO} 2$ between the atmosphere, the land-sea interface and the ocean. Geophysical Research Letters 30, 1849, doi:10.1029/2003GL017633.

25. Cai W.-J. and Y. Wang. 1998. The chemistry, fluxes and sources of carbon dioxide in the estuarine waters of the Satilla and Altamaha Rivers, Georgia. Limnology and Oceanography, 43:657-668.

26. Chavez F.P. and M. Messié (2009) A Comparison of Eastern Boundary Upwelling Ecosystems. Progress in Oceanography, 83: 80-96.

27. Chavez, F.P., T. Takahashi, W.-J. Cai, G. Friederich, B. Hales, R. Wanninkhof, and R.A. Feely (2007) Coastal Oceans, Chapter 15 in The First State of the Carbon Cycle Report (SOCCR): The North American Carbon Budget and Implications for the Global Carbon Cycle, Synthesis and Assessment Product 2.2, Report by the U.S. Climate Change Science Program and the Subcommittee on Global Change Research, A.W. King, L. Dilling, G.P. Zimmerman, D.M. Fairman, R.A. Houghton, G. Marland, A.Z. Rose, and T.J. Wilbanks (eds.), 157-166.

28. Chen CTA 2002. Shelf- vs. dissolution-generated alkalinity about the chemical lysocline. Deep Sea Research II, 49, 5365-5375.

29. Chen C.T.A. \& A.V. Borges (2009) Reconciling opposing views on carbon cycling in the coastal ocean: continental shelves as sinks and near-shore ecosystems as sources of atmospheric CO2, Deep-Sea Research II, 56 (8-10), 578-590, doi:10.1016/j.dsr2.2009.01.001.

30. Chen L-H and X-yun Zhang (2009) Application of Artificial Neural Networks to Classify Water Quality of the Yellow River, Advances in Soft Computing, 54, $15-23$.

31. Chierici M. and A. Fransson (2009) Calcium carbonate saturation in the surface water of the Arctic Ocean: undersaturation in freshwater influenced shelves, Biogeosciences Discuss. 6, 4963-4991.

32. Cloern J.E. and A.D. Jassby (2008) Complex seasonal patterns of primary producers at the land-sea interface, Ecology Letters, 11: 1294-1303.

33. Cole J.J., Y.T. Prairie, N. F. Caraco, W. H. McDowell, L. J. Tranvik, R. G. Striegl, C. M. Duarte, P. Kortelainen, J. A. Downing, J. J. Middelburg, and J.
Melack (2007) Plumbing the Global Carbon Cycle: Integrating Inland Waters into the Terrestrial Carbon Budget, Ecosystems 10: 171-184

34. Cole, J.J., Caraco, N.F., 2001. Carbon in catchments: connecting terrestrial carbon losses with aquatic metabolism. Marine and Freshwater Research 52(1), 101-110.

35. Cole, J.J., Caraco, N.F., Kling, G.W., Kratz, T.K., 1994 Carbon dioxide supersaturation in the surface waters of lakes. Science 265(5178), 1568-1570.

36. Dai M., Z. Lu, W. Zhai, B. Chen, Z. Cao, K. Zhou, W.-J. Cai, and C.-T.A. Chen (2009) Diurnal variations of surface seawater pCO2 in contrasting coastal environments, Limnology \& Oceanography, 54(3), 735-745.

37. Delille B., J. Harlay, I. Zondervan, S. Jacquet, L. Chou, R. Wollast, R.G.J. Bellerby, M. Frankignoulle, A.V. Borges, U. Riebesell \& J.-P. Gattuso (2005) Response of primary production and calcification to changes of pCO2 during experimental blooms of the coccolithophorid Emiliania huxleyi, Global Biogeochemical Cycles, 19, GB2023, doi:10.1029/2004GB002318.

38. Di Lorenzo E., Miller A.J., Schneider N. and McWilliams J.C. (2005) The Warming of the California Current System: Dynamics and Ecosystem Implications, Journal of Physical Oceanography, 35(3), 336-362.

39. Diffenbaugh, N. S., M. A. Snyder, and L. C. Sloan. 2004. Could CO2-induced land-cover feedbacks alter near-shore upwelling regimes? Proceedings of the National Academy of Sciences of the United States of America 101(1):27-32.

40. Doney S.C., N. Mahowald,I. Lima,R.A. Feely, F.T. Mackenzie,J.-F. Lamarque, P.J. Rasch (2007) Impact of anthropogenic atmospheric nitrogen and sulfur deposition on ocean acidification and the inorganic carbon system, Proceedings of the National Academy of Sciences, 104(37), 14580-14585.

41. Doney, S.C., V.J. Fabry, R.A. Feely, J.A. Kleypas, 2009: Ocean acidification: the other CO2 problem, Ann. Rev. Mar. Sci., 1, 169-192.

42. Duarte, C. M. 2002. The future of seagrass meadows. Environmental Conservation 29(2):192-206.

43. Emerson, S., C. Stump, and D. Nicholson (2008), Net biological oxygen production in the ocean: Remote in situ measurements of $\mathrm{O} 2$ and N2 in surface waters, Global Biogeochem. Cycles, 22, GB3023, doi:10.1029/2007GB003095.

44. Engel, A., U. Thoms, U. Riebesell, E. Rochelle-Newall, and I. Zondervan. 2004. Polysaccharide aggregation as a potential sink of marine dissolved organic carbon. Nature 428: 929-932.

45. Engel A., I. Zondervan, K. Aerts, L. Beaufort, A. Benthien, L. Chou, B. Delille, J.-P. Gattuso, J. Harlay, C. Heemann, L. Hoffmann, S. Jacquet, J. Nejstgaard, M.-D. Pizay, E. Rochelle-Newall, U. Schneider, A. 
Terbrueggen A. \& U. Riebesell (2005) Testing the direct effect of $\mathrm{CO} 2$ concentration on a bloom of the coccolithophorid Emiliania huxleyi in mesocosm experiments, Limonology and Oceanography, 50(2): 493-507

46. Fagan K.E. and F.T. Mackenzie (2007) Air-sea CO2 exchange in a subtropical estuarine-coral reef system, Kaneohe Bay, Oahu, Hawaii, Marine Chemistry 106 174-191

47. Feely R.A., C.L. Sabine, J.M. Hernandez-Ayon, D. Ianson, B. Hales (2008) Evidence for Upwelling of Corrosive "Acidified" Water onto the Continental Shelf, Science 320: 1490-1492. doi:10.1126/science.1155676

48. Feely, R.A., J. Orr, V.J. Fabry, J.A. Kleypas, C.L. Sabine, and C. Langdon. 2009. Present and future changes in seawater chemistry due to ocean acidification. Section 3 in Carbon Sequestration and Its Role in the Global Carbon Cycle. B.J. McPherson and E.T. Sundquist, eds, Geophysical Monograph Series, Vol. 83, American Geophysical Union, Washington, DC.

49. Feely, R. \& Co-Authors (2010). "An International Observational Network for Ocean Acidification" in these proceedings (Vol. 2), doi:10.5270/OceanObs09.cwp.29.

50. Fennel, K., J. Wilkin, M. Previdi, and R. Najjar (2008), Denitrification effects on air-sea CO2 flux in the coastal ocean: Simulations for the northwest North Atlantic, Geophys. Res. Lett., 35, L24608, doi:10.1029/2008GL036147.

51. Field, D. Cayan, D. Chavez, F. (2006) Secular Warming in the California Current and North Pacific, California Cooperative Oceanic Fisheries Investigations Report, $47,92-110$.

52. Frankignoulle M. \& A.V. Borges (2001) European continental shelf as a significant sink for atmospheric carbon dioxide, Global Biogeochemical Cycles, 15(3): 569-576

53. Frankignoulle M., G. Abril, A. Borges, I. Bourge, C. Canon, B. Delille, E. Libert \& J.-M. Théate (1998) Carbon Dioxide Emission From European Estuaries, Science, 282: 434-436.

54. Frankignoulle M., I. Bourge \& R. Wollast (1996) Atmospheric $\mathrm{CO} 2$ fluxes in a highly polluted estuary (The Scheldt), Limnology and Oceanography, 41(2): 365-369.

55. Friederich, G. E., P. M. Walz, M. G. Burczynski, and F. P. Chavez. 2002. Inorganic carbon in the central California upwelling system during the 1997-1999 El Niño-La Niña event. Progress in Oceanography 54(14):185-203.

56. Friederich, G.E., J. Ledesma, O. Ulloa, F.P. Chavez (2008) Air-sea carbon dioxide fluxes in the coastal southeastern tropical Pacific, Progress in Oceanography, 79(2-4) 156-166.
57. Friedrich T., A. Oschlies (2009) Neural-network based estimates of North Atlantic surface pCO2 from satellite data - a methodological study, Journal of Geophysical, 114, C03020, doi:10.1029/2007JC004646, 2009.

58. García-Muñoza M., J. Arístegui, J. L. Pelegrí, A Antoranz, A. Ojeda, M. Torres (2005) Exchange of carbon by an upwelling filament off Cape Ghir (NW Africa) Journal of Marine Systems 54:83-95.

59. Gattuso, J.-P., M. Frankignoulle, and R. Wollast. 1998a. Carbon and carbonate metabolism in coastal aquatic ecosystems. Ann. Rev. Ecol. Syst. 29: 405-433.

60. Gattuso, J.-P., M. Frankignoulle, I. Bourge, S. Romaine, and R. W. Buddemeier. 1998b. Effect of calcium carbonate saturation of seawater on coral calcification. Global and Planetary Change 18(1-2):37-46.

61. Gledhill, D. K., R. Wanninkhof, F. J. Millero, and M. Eakin (2008), Ocean acidification of the Greater Caribbean Region 1996-2006, J. Geophys. Res., 113, C10031, doi:10.1029/2007JC004629.

62. Goyet, C., F. J. Millero, D. W. O'Sullivan, G. Eischeid, S. J. McCue, and R. G. J. Bellerby. 1998. Temporal variations of $\mathrm{pCO}_{2}$ in surface seawater of the Arabian sea in 1995. Deep-Sea Research Part I 45(4-5):609623.

63. Gypens N., A.V. Borges \& C. Lancelot (2009) Effect of eutrophication on air-sea $\mathrm{CO} 2$ fluxes in the coastal Southern North Sea: a model study of the past 50 years, Global Change Biology, 15(4), 1040-1056.

64. Hales, B., T. Takahashi, and L. Bandstra (2005), Atmospheric $\mathrm{CO} 2$ uptake by a coastal upwelling system, Global Biogeochem. Cycles, 19, GB1009, doi:10.1029/2004GB002295.

65. Holt, Jason; Wakelin, Sarah; Huthnance, John. 2009 Down-welling circulation of the northwest European continental shelf: A driving mechanism for the continental shelf carbon pump. Geophysical Research Letters, 36, L14602. doi:10.1029/2009GL038997

66. Hughes, T. P., A. H. Baird, D. R. Bellwood, M. Card, S. R. Connolly, C. Folke, R. Grosberg, O. HoeghGuldberg, J. B. C. Jackson, J. Kleypas, J. M. Lough, P. Marshall, M. Nystrom, S. R. Palumbi, J. M. Pandolfi, B. Rosen, and J. Roughgarden. 2003. Climate change, human impacts, and the resilience of coral reefs. Science 301(5635):929-933.

67. Jamet, C., Moulin, C; Lefevre, N (2007) Estimation of the oceanic $\mathrm{pCO}_{2}$ in the North Atlantic from VOS lines in-situ measurements: parameters needed to generate seasonally mean maps, Annales Geophysical, 25(11), 2247-2257.

68. Ji, R. B., Davis, C. Chen, C. S. Beardsley, R.2008 Influence of local and external processes on the annual nitrogen cycle and primary productivity on Georges Bank: A 3-D biological-physical modeling study Journal of Marine Systems, 73, 37-41. 
69. Jiang L.-Q., Cai, W.-J., Wanninkhof, R., Wang, Y., Hüger, H., 2008. Air-sea CO2 fluxes on the U.S. South Atlantic Bight: spatial and seasonal variability. Journal of Geophysical Research, 113, C07019, 17 pp., 2008, doi:10.1029/2007JC004366.

70. Johnson, K. S. (2009) Simultaneous measurements of nitrate, oxygen and dissolved inorganic carbon on oceanographic moorings: Observing the Redfield Ratio in real-time. Limnol. Oceanogr., 55(2), 2010, 615-627. doi:10.4319/lo.2010.55.2.0615.

71. Johnson, K. S., L. J. Coletti, and F. P. Chavez (2006) Diel nitrate cycles observed with in situ sensors predict monthly and annual new production. Deep-Sea Res. I 53: 561-573.

72. Karl D.M., E.A. Laws, P. Morris, P.J. leB.Williams and S. Emerson (2003) Metabolic balance of the open sea, Nature 426: 32.

73. Kleypas, J. A., R. W. Buddemeier, D. Archer, J. P. Gattuso, C. Langdon, and B. N. Opdyke. 1999. Geochemical consequences of increased atmospheric carbon dioxide on coral reefs. Science 284(5411):118120.

74. Kuliński K. and J. Pempkowiak (2008) Dissolved organic carbon in the southern Baltic Sea: Quantification of factors affecting its distribution, Estuarine, Coastal and Shelf Science 78: 38-44.

75. Kortzinger, A., et al. (2008) The seasonal pCO2 cycle at $49^{\circ} \mathrm{N} / 16.5^{\circ} \mathrm{W}$ in the northeastern Atlantic Ocean and what it tells us about biological productivity. J. Geophys. Res. 113: C04020, doi:10.1029/2007JC004347.

76. Lagerloef, G. \& Co-Authors (2010). "Resolving the Global Surface Salinity Field and Variations by Blending Satellite and In Situ Observations" in these proceedings (Vol. 2), doi:10.5270/OceanObs09.cwp.51.

77. Lee, K., L.T. Tong, F.J. Millero, C.L. Sabine, A.G. Dickson, C. Goyet, G.-H. Park, R. Wanninkhof, R.A. Feely, and R.M. Key. 2006. Global relationships of total alkalinity with salinity and temperature in surface waters of the world's oceans. Geophysical Research Letters, 33, L19605, doi:10.1029/2006GL027207.

78. Lefèvre N., J. Aiken, J. Rutllant, G. Daneri, S. Lavender, T. Smyth (2002) Observations of pCO2 in the coastal upwelling off Chile: Spatial and temporal extrapolation using satellite data, Journal of Geophysical Research, Vol. 107, NO. C6, doi:10.1029/2000JC000395.

79. Lefèvre, N., A. J. Watson, A. Olsen, A. F. Ríos, F. F. Pérez, and T. Johannessen (2004), A decrease in the sink for atmospheric $\mathrm{CO} 2$ in the North Atlantic, Geophys. Res. Lett., 31, L07306, doi:10.1029/2003GL018957.

80. Lefèvre, N; Watson, AJ; Watson, AR (2005) A comparison of multiple regression and neural network techniques for mapping in situ $\mathrm{pCO}_{2}$ data, Tellus $B$, 57(5), 375-384.
81. Lehner, B., Döll, P., 2004. Development and validation of a global database of lakes, reservoirs and wetlands. Journal of Hydrology 296(1-4), 1-22.

82. Liu K-K, L Atkinson, R Quinones, L Talaue-McManus (2009) Carbon and Nutrient Fluxes in Continental Margins: A Global Synthesis. Springer-Verlag New York.

83. Ludwig W., P. Amiotte-Suchet and J.-L. Probst (1996a) River discharges of carbon to the world's oceans: determining local inputs of alkalinity and of dissolved and particulate organic carbon, C.R. Acad. Sci. Paris II, 323, 1007-1014.

84. Ludwig, W., Probst, J.L., Kempe, S., 1996b. Predicting the oceanic input of organic carbon by continental erosion. Global Biogeochemical Cycles 10(1), 23-41.

85. Mackenzie, F. T., A. Lerman, and A. J. Andersson. 2004. Past and present of sediment and carbon biogeochemical cycling models. Biogeosciences 1(1):11-32.

86. Manabe, S., P. C. D. Milly, and R. Wetherald. 2004 Simulated long-term changes in river discharge and soil moisture due to global warming. Hydrological Sciences Journal-Journal des Sciences Hydrologiques 49(4):625-642.

87. Martz, T. R, K. S. Johnson and S. C. Riser (2008.) Ocean metabolism observed with oxygen sensors on profiling floats in the Pacific. Limnol. Oceanogr., 53(5_part_2), 2008, 2094-2111. doi:10.4319/lo.2008.53.5_part_2.2094.

88. Martz, T. R., M. D. DeGrandpre, P. G. Strutton, W. R. McGillis and W. M. Drennan (2009). Sea surface pCO2 and carbon export during the Labrador Sea spring-summer bloom: an in situ mass balance approach. Journal of Geophysical Research, doi:10.1029/2008JC005060.

89. Malone, T. \& Co-Authors (2010). "Building a Global System of Systems for the Coastal Ocean: A Strategic Action Plan for Implementing the Coastal Module of GOOS" in these proceedings (Vol. 2), doi:10.5270/OceanObs09.cwp.59.

90. Matear, R. J., and A. C. Hirst (2003), Long-term changes in dissolved oxygen concentrations in the ocean caused by protracted global warming, Global Biogeochem. Cycles, 17(4), 1125, doi:10.1029/2002GB001997.

91. McGregor H.V., M. Dima, H. W. Fischer, S. Mulitza (2007) Rapid 20th-Century Increase in Coastal Upwelling off Northwest Africa, Science, 315, 637639.

92. Meybeck, M. 1993. Natural sources of C, N, P and S, p. 163-193. In R. Wollast, F. T. Mackenzie, and L. Chou (eds.), Interactions of $C, N, P$ and $S$ Biogeochemical Cycles.

93. Milliman, J. D. 1991. Flux and fate of fluvial sediments and water in coastal seas, p. 69-90. In R. F. C. Mantoura, J.-M. Martin and R. Wollast (eds.), Ocean margin processes in global change. John Wiley \& 
Sons, Chichester, New York, Brisbane, Toronto, Singapore.

94. Monteiro, P. \& Co-Authors (2010). "A Global Sea Surface Carbon Observing System: Assessment of Changing Sea Surface CO2 and Air-Sea CO2 Fluxes" in these proceedings (Vol. 2), doi:10.5270/OceanObs09.cwp.64

95. Okkonen S.R., G.M. Schmidt, E.D. Cokelet, P.J. Stabeno (2004) Satellite and hydrographic observations of the Bering Sea 'Green Belt', Deep-sea research II, 51:1033-1051.

96. Oliver, M. J., S. Glenn, J. T. Kohut, A. J. Irwin, O. M. Schofield, M. A. Moline and W. P. Bissett. 2004. Bioinformatic approaches for objective detection of water masses on continental shelves. Journal of Geophysical Research 109(C7):C07S04doi:10.1029/2003JC002072.

97. Olsen A., J.A. Trinanes, R. Wanninkhof (2004) Sea-air flux of $\mathrm{CO} 2$ in the Caribbean Sea estimated using in situ and remote sensing data, Remote Sensing of Environment 89: 309-325.

98. Pain, C.C., Piggott, M.D., Goddard, A.J.H., Fang, F., Gorman, G.J., Marshall, D.P., Eaton, M.D., Power, P.W. and de Oliveira, C.R.E., 2005. Threedimensional unstructured mesh ocean modelling. Ocean Modelling, 10(1-2): 5-33.

99. Paquay F.S., F.T. Mackenzie \& A.V. Borges (2007) Carbon dioxide dynamics in rivers and coastal waters of the "Big Island" of Hawaii, USA, during baseline and heavy rain condition, Aquatic Geochemistry, 13(1), 1-18

100. Patsch J, Kuhn W (2008) Nitrogen and carbon cycling in the North Sea and exchange with the North Atlantic A model study. Part I. Nitrogen budget and fluxes. Continental shelf Research 28, 767-787.

101. Paulmier A., D. Ruiz-Pino, V. Garçon (2008) The oxygen minimum zone (OMZ) off Chile as intense source of $\mathrm{CO}_{2}$ and $\mathrm{N}_{2} \mathrm{O}$, Continental Shelf Research $28,2746-2756$.

102. Raimbault P., N. Garcia, and F. Cerutti (2007) Distribution of inorganic and organic nutrients in the South Pacific Ocean - evidence for long-term accumulation of organic matter in nitrogen-depleted waters, Biogeosciences Discuss., 4, 3041-3087.

103. Rangama Y., J. Boutin ,.J. Etcheto, L. Merlivat, T. Takahashi, B. Delille, M. Frankignoulle, \& D.C.E. Bakker (2005) Variability of net air-sea CO2 flux inferred from in situ and satellite measurements in the Southern Ocean south of Tasmania and New Zealand, Journal of Geophysical Research, 110(C9), C09005, doi:10.1029/2004JC002619.

104. Raymond, P. A. and J. J. Cole. 2003. Increase in the export of alkalinity from North America's largest river. Science 301(5629):88-91.
105. Raymond, P.A., N.H. Oh, R.E. Turner, and W. Broussard. 2008. Anthropogenically enhanced fluxes of water and carbon from the Mississippi River. Nature 451, 449-452.

106. Riebesell, U. 2004. Effects of CO2 enrichment on marine phytoplankton. Journal of Oceanography 60(4):719-729.

107. Riebesell, U., I. Zondervan, B. Rost, P. D. Tortell, R. Zeebe, and F. M. M. Morel. 2000. Reduced calcification of marine plankton in response to increased atmospheric $\mathrm{CO}_{2}$. Nature 407(6802):364367.

108. Riebesell U., Schulz K. G., Bellerby R. G. J., Botros M., Fritsche P., Meyerhofer M., Neill C., Nondal G., Oschlies A., Wohlers J., and Zollner E. (2007) Enhanced biological carbon consumption in a high CO2 ocean. Nature 450, 545-548.

109. Riser, S.C. and K.S. Johnson (2008) Net production of oxygen in the subtropical ocean. Nature 451: 323-326.

110. Ruddick, K.G., F. Ovidio, and M. Rijkeboer (2000) Atmospheric correction of SeaWiFS imagery for turbid coastal and inland waters. Applied Optics. 39(6): p. 897-912.

111. Salisbury J., D. Vandemark, C. Hunt, J. Campbell, B. Jonsson, A. Mahadevan, W. McGillis, H. Xue (2009) Episodic riverine influence on surface DIC in the coastal Gulf of Maine, Estuarine, Coastal and Shelf Science 82: 108-118.

112. Salisbury J.E., D. Vandemark, C.W. Hunt, J.W. Campbell, W.R. McGillis, W.H. McDowell (2008) Seasonal observations of surface waters in two Gulf of Maine estuary-plume systems: Relationships between watershed attributes, optical measurements and surface pCO2, Estuarine, Coastal and Shelf Science 77: 245252

113. Salisbury, J., M. Green, C. Hunt, and J. Campbell (2008), Coastal acidification by rivers: A new threat to shellfish? Eos Trans. AGU, 89(50), 513.

114. Santana-Casiano, J. M., M. Gonzalez-Davila, M.-J. Rueda, O. Llinas, and E.-F. Gonzalez-Davila (2007), The interannual variability of oceanic $\mathrm{CO}_{2}$ parameters in the northeast Atlantic subtropical gyre at the ESTOC site, Global Biogeochem. Cycles, 21, GB1015, doi:10.1029/2006GB002788.

115. Schiettecatte, L.-S., Thomas, H., Bozec, Y., Borges, A.V., 2007. High temporal coverage of carbon dioxide measurements in the Southern Bight of the North Sea. Marine Chemistry 106 (1-2), 161-173.

116. Shin, K.-H., and N. Tanaka (2004), Distribution of dissolved organic matter in the eastern Bering Sea, Chukchi Sea (Barrow Canyon) and Beaufort Sea, Geophys. Res. Lett., 31, L24304, doi:10.1029/2004GL021039. 
117. Short, F. T. and H. A. Neckles. 1999. The effects of global climate change on seagrasses. Aquatic Botany 63(3-4):169-196.

118. Seidel, M.P., DeGrandpre, M.D. and A.G. Dickson. 2008. A sensor for in situ indicator-based measurements of seawater pH, Mar. Chem., 109, 1828.

119. Smith, S. V., D. P. Swaney, L. Talaue-McManus, J. D. Bartley, P. T. Sandhei, C. J. McLaughlin, V. C. Dupra, C. J. Crossland, R. W. Buddemeier, B. A. Maxwell, and F. Wulff. 2003. Humans, hydrology, and the distribution of inorganic nutrient loading to the ocean. BioScience 53(3):235-245.

120. Snyder, M. A., L. C. Sloan, N. S. Diffenbaugh, and J. L. Bell. 2003. Future climate change and upwelling in the California Current. Geophysical Research Letters 30(15):1823-doi:10.1029/2003GL017647.

121. Stramma L., G. C. Johnson, J. Sprintall, V. Mohrholz (2008) Expanding Oxygen-Minimum Zones in the Tropical Oceans, Science, 320, 655-658.

122. Takahashi T., S.C. Sutherland, R. Wanninkhof, C. Sweeney, R.A. Feely, D. W. Chipman, B. Hales, G. Friederich, F. Chavez, C. Sabine, A. Watson, D.C.E. Bakker, U. Schuster, N. Metzl, Hi. Yoshikawa-Inoue, M. Ishii, T. Midorikawa, Y. Nojiri, A. Körtzinger, T; Steinhoff, M. Hoppema, J. Olafsson, T.S. Arnarson, B. Tilbrook, T. Johannessen, A. Olsen, R. Bellerby, C.S. Wong , B. Delille, N.R. Bates, H.J.W. de Baar (2009), Climatological Mean and Decadal Change in Surface Ocean $\mathrm{pCO}_{2}$, and Net Sea-air $\mathrm{CO}_{2}$ Flux over the Global Oceans, Deep Sea Research Part II: Topical Studies in, Oceanography, Volume 56, Issues 8-10, Pages 554-577. doi:10.1016/j.dsr2.2008.12.009.

123. Takahashi, T., Sutherland, S.C., Feely, R.A., Wanninkhof, R., 2006. Decadal change of the surface water $\mathrm{pCO}_{2}$ in the North Pacific: A synthesis of 35 years of observations, Journal of Geophysical Research 111(C7), C07S05, doi:10.1029/2005JC003074.

124. Telszewski M., A. Chazottes, U. Schuster, A.J. Watson, C. Moulin, D.C.E. Bakker, M. Gonzalez-Davila, T. Johannessen, A. Koertzinger, H. Lueger, A. Olsen, A. Omar, X.A. Padin, A. Rios, T. Steinhoff, M. SantanaCasiano, D.W.R. Wallace, and R. Wanninkhof (2009) Estimating the monthly pCO2 distribution in the North Atlantic using a self-organizing neural network, Biogeosciences Discussions, 6, 3373-3414.

125. Thomas, H., Bozec, Y., Elkalay, K., de Baar, H.J.W., 2004. Enhanced open ocean storage of CO2 from shelf sea pumping. Science 304, 1005, doi:10.1126/science.1095491.

126. Thomas, H., F. Prowe, S. van Heuven, Y. Bozec, H.J.W. de Baar, L.-S. Schiettecatte, K. Suykens, M. Koné, A.V. Borges, I.D. Lima, S.C. Doney (2007) Rapid decline of the $\mathrm{CO}_{2}$ buffering capacity in the North Sea and implications for the North Atlantic Ocean, Global Biogeochemical Cycles, 21 (GB4001), doi:10.1029/2006GB002825.
127. Thomas H., L.-S. Schiettecatte, K. Suykens, Y.J.M Koné, E. H. Shadwick, A.E.F. Prowe, Y. Bozec, H.J.W. de Baar \& A. V. Borges (2009) Enhanced ocean carbon storage from anaerobic alkalinity generation in coastal sediments, Biogeosciences, $6,1-8$

128. Vlahos, P, R.F. Chen, D.J. Repeta, (2002) Dissolved organic carbon in the Mid-Atlantic Bight, Deep-Sea Res. II, 49(20), 4369-4385.

129. Vörösmarty, C. J. and D. Sahagian. 2000 Anthropogenic disturbance of the terrestrial water cycle. BioScience 50(9):753-765.

130. Vörösmarty, C. J., M. Meybeck, B. Fekete, K. Sharma, P. Green, and J. P. M. Syvitski. 2003. Anthropogenic sediment retention: major global impact from registered river impoundments. Global and Planetary Change 39(1-2):169-190.

131. Wakita, M., S. Watanabe, Y. W. Watanabe, T. Ono, N. Tsurushima, and S. Tsunogai (2005), Temporal change of dissolved inorganic carbon in the subsurface water at Station $\mathrm{KNOT}\left(44^{\circ} \mathrm{N}, 155^{\circ} \mathrm{E}\right)$ in the western North Pacific subpolar region, J. Oceanogr., 61(1), 129- 139 .

132. Walsh, J. J. 1988. On the nature of continental shelves. Academic Press, San Diego, New York, Berkeley, Boston, London, Sydney, Tokyo, Toronto.

133. Warrick, J.A. and D.A. Fong, 2004. Dispersal scaling from the world's rivers. Geophysical Research Letters, 31, L04301, doi: 10. 1029/2003GL019114.

134. Wolf-Gladrow, D. A., U. Riebesell, S. Burkhardt, and J. Bijma. 1999. Direct effects of $\mathrm{CO}_{2}$ concentration on growth and isotopic composition of marine plankton. Tellus Series B 51(2):461-476.

135. Wong, C. S., F. A. Whitney, D. W. Crawford, K. Iseki, R. J. Matear, W. K. Johnson, and J. S. Page (1999), Seasonal and interannual variability in particle fluxes of carbon, nitrogen and silicon from time series of sediment traps at Ocean Station P, 1982 - 1993: Relationship to changes in subarctic primary productivity, Deep Sea Res., Part II, 46, 2735- 2760.

136. Woodwell, G.M., Rich, P.H., Hall, C.A.S., 1973. Carbon in estuaries. In: Woodwell, G.M., Pecan, E.V. (Eds.), Carbon and the Biosphere, Springfield, Virginia, 221240 .

137. Zhai W. and M. Dai (2009) On the seasonal variation of air-sea $\mathrm{CO}_{2}$ fluxes in the outer Changjiang (Yangtze River) Estuary, East China Sea, Marine Chemistry, Vol. 117, Issues 1-4, 20 December 2009, Pages 2-10, doi:10.1016/j.marchem.2009.02.008.

138. Zondervan, I., B. Rost, and U. Riebesell. 2002. Effect of $\mathrm{CO} 2$ concentration on the $\mathrm{PIC} / \mathrm{POC}$ ratio in the coccolithophore Emiliania huxleyi grown under lightlimiting conditions and different day lengths. Journal of Experimental Marine Biology and Ecology 272(1):55-70. 